\title{
Neotrance and the Psychedelic Festival
}

\author{
GRAHAM ST JOHN \\ UNIVERSITY OF REGINA, UNIVERSITY OF QUEENSLAND
}

\begin{abstract}
This article explores the religio-spiritual characteristics of psytrance (psychedelic trance), attending specifically to the characteristics of what I call neotrance apparent within the contemporary trance event, the countercultural inheritance of the "tribal" psytrance festival, and the dramatizing of participants' "ultimate concerns" within the festival framework. An exploration of the psychedelic festival offers insights on ecstatic (selftranscendent), performative (self-expressive) and reflexive (conscious alternative) trajectories within psytrance music culture. I address this dynamic with reference to Portugal's Boom Festival.
\end{abstract}

\section{Keywords}

psytrance, neotrance, psychedelic festival, trance states, religion, new spirituality, liminality, neotribe

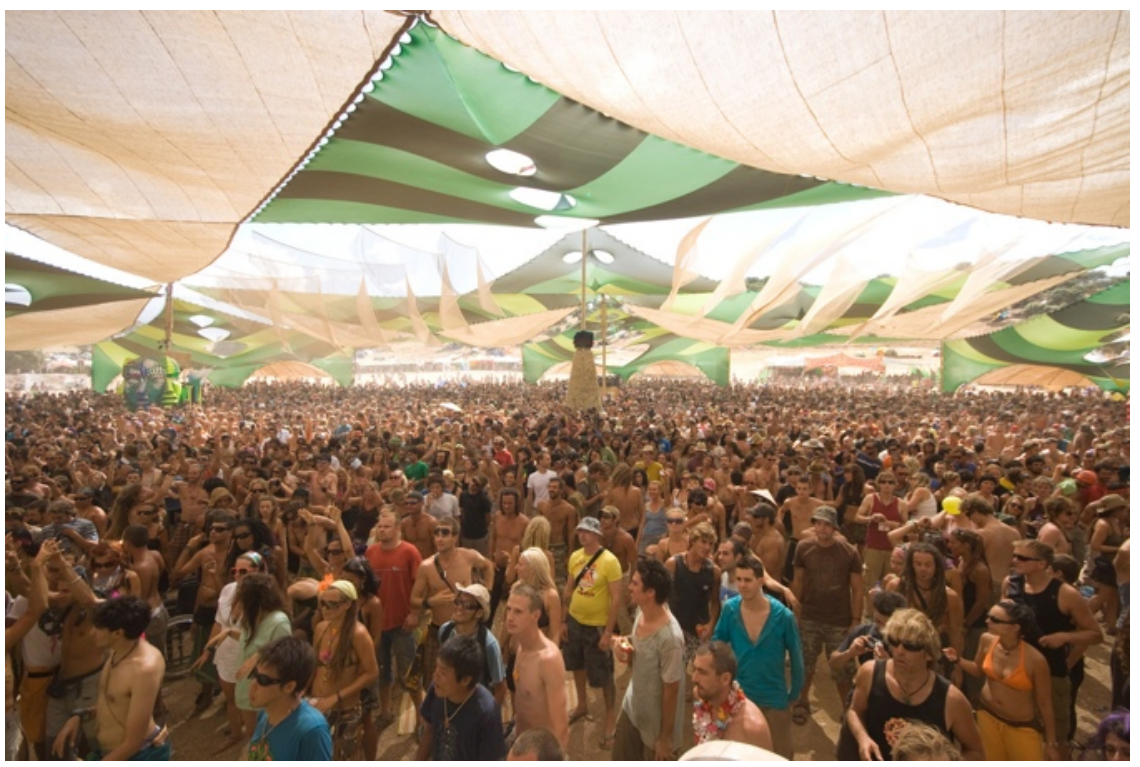

Figure 1: Main Floor, Boom Festival 2008, Portugal - Photo by jakob kolar www.jacomedia.net

As electronic dance music cultures (EDMCs) flourish in the global present, their religious and/or spiritual character have become common subjects of exploration for scholars of religion, music and culture. ${ }^{1}$ This article addresses the religio-spiritual 
characteristics of psytrance (psychedelic trance), attending specifically to the characteristics of the contemporary trance event which I call neotrance, the countercultural inheritance of the "tribal" psytrance festival, and the dramatizing of participants' "ultimate concerns" within the framework of the "visionary" music festival. Discussion of these characteristics within the psychedelic festival offers insight on ecstatic (selftranscendent), performative (self-expressive) and reflexive (conscious alternative) trajectories within psytrance music culture. Insight is gained on these tendencies through attention to Portugal's Boom Festival, the premier event in the international psytrance calendar.

Initiated in 1997, and held on lake Idanha-a-Nova near the village by that name in the mountainous Portuguese Beira Baixa province, the biennial Boom Festival has become a pilgrimage centre for the global psytrance community. I conducted field research at Boom in August 2006 and again in August 2008, when, on both occasions, some $25,000^{2}$ psytrance enthusiasts from an estimated eighty-five countries camped out for up to seven days on the festival site in sweltering conditions. Promoted by its organising body, Good Mood Productions, as a week long "visionary arts festival", a "harmonic convergence of people, energy, information and philosophies from around the planet earth and beyond", and commanding "a balance of the organic and the cyber-technologic",3 Boom accommodates diverse countercultural strands drawn towards ecstatic trance and visionary culture. The event features multiple EDM sound stages. Operating for twenty-three hours a day for six days, and catering for around 5,000 people at any one time, the Main Floor features high-performance audio, lighting and water misting systems designed for enhancing expressive/transcendent states. ${ }^{4}$ Over 100 DJs from many different countries perform a range of electronic trance genres in the main arena, including "progressive psychedelic", "full on" and "darkpsy". The former style (sometimes called "morning trance") typically incorporates soaring melodies around persistent and seductive bass lines (a distinctive stream of sixteenth notes over a 4/4 rhythm, and usually 135-145 BPM). Traceable to Israel and the HOMMega label, "full on" features productions possessing a typically relentless rolling bass line, which, while at 140-150 BPM, usually holds two or three short bass notes between each 4/4 note. Crystalising in Germany and Russia with influences from industrial styles, the increasingly popular darkpsy (or "night trance") adopts a faster, sometimes furious, pace (150-170+ BPM) typically lifting audio dialogue from horror cinema. Derivative of the "chillout" development within EDMC, the Ambient Stage (a Balinese pagoda in 2006, and called the Ambient Forest in 2008) features a central DJ performance area where artists play down-tempo ambient musics (sometimes called "psybient", and often possessing world music or "ethnodelic" samples) to an audience reclining on the surrounding cushioned matting. At the Groovy Beach stage, which was upgraded significantly in 2008 , the dance floor is subjected to an eclectic fusion of sounds (including techno, glitch and dub step), with a funky "electro" aesthetic predominating. In addition to the three EDM stages, Boom hosts a World Music stage, also referred to as the "Sacred Fire" area given the presence of a fire pit constructed according to principles derived from world Rainbow Gatherings. 5 Here bands from several continents typically perform world music styles (for example, using djembe, gamelan, didjeridu) and techno-acoustic fusion styles. ${ }^{6}$ Other significant features of the Boom environment are a market area (featuring chai tents, food stalls with many natural and vegetarian options, clothing and jewelry shops shifting imported goods from India and sometimes local designs, and art and music stalls), the Eco Village (with displays and workshops on the ecological sustainability projects undertaken by 
Boom), and the Liminal Village (an area for workshops and presentations, as discussed below).

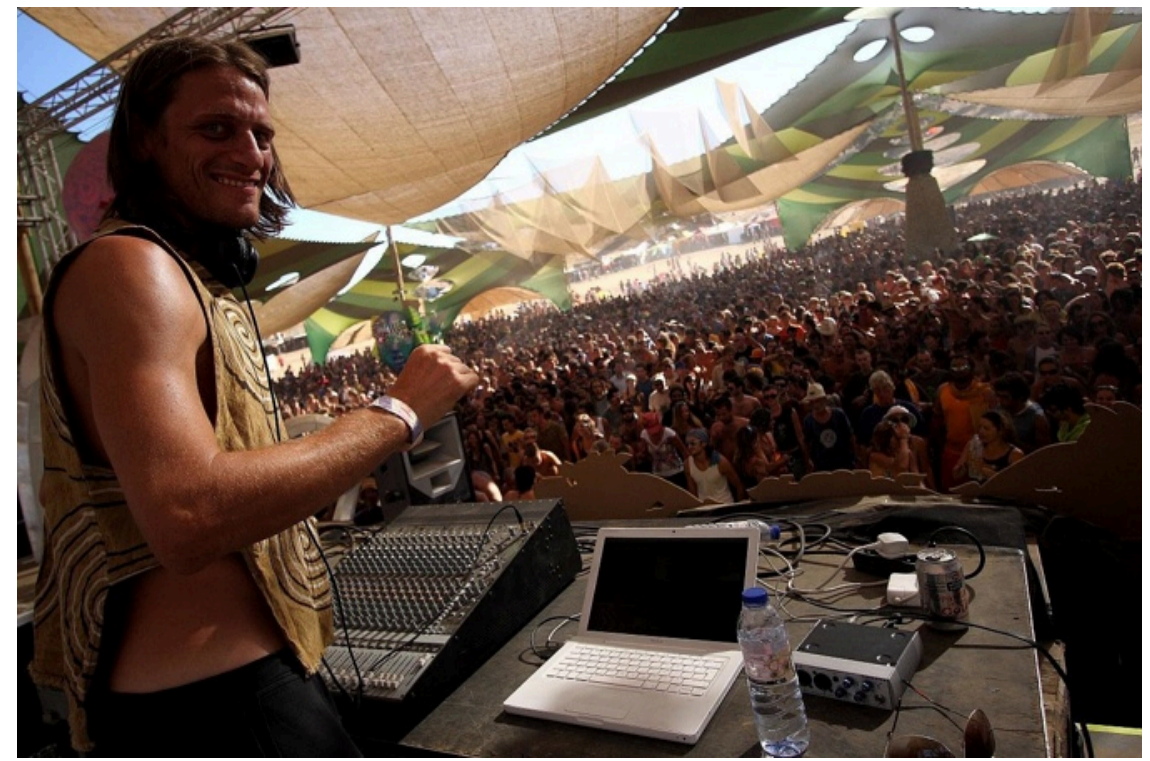

Figure 2: DJ Tristan at Boom Festival Main Floor 2008: Photo by Alex Canezei

www.alexcanazei.com

I will return to Boom (and psytrance) following a review of approaches to EDMC and religion. The growing interest in the religious dimensions of EDMC is characterised by a diversity of analysis and debate. For instance, while the abuse and misuse of popular dance drugs (such as MDMA or "Ecstasy", and methamphetamine or "speed") may be considered to have precipitated the "darkside" of one of EDMC's most popular developments, rave (Reynolds 1997), others call to attention Ecstasy's ostensible ability to "foster spirituality, personal development and life change" (Takahashi 2004: 151; see also Saunders and Doblin 1996; Saunders, Saunders and Pauli 2000). In the popular works of Irvine Welsh, Ecstasy constitutes a "spiritual technology" offering the potential to "shift consciousness towards the transcendental goal of better communications with one's spiritual self” (Stephenson 2003:154). While psychoactive mind-alterants circulate at a rate faster than the ability of researchers to keep up, Anthony D'Andrea's (2004: 249) remarks that the "limit experience" precipitated by psychedelics in particular (such as LSD or "acid") may be "sublime or traumatic", seem sanguine. That EDMCs contextualise collective alterations of consciousness, especially among youth, has triggered a range of passions: from moral panics and hysteria such as that expressed by Christian fundamentalists, ${ }^{7}$ to statements of self-awakening, ${ }^{8}$ and other material produced by rave-evangelists (see Fritz 1999) and enthused filmmakers like Torsten Kilmmer (Omananda) and Billy Rood (Tantric Demon), who produced the film popular among psytrance enthusiasts Liquid Crystal Vision (2002).

While dance, as Ann Wagner (1997) conveys in her Adversaries of Dance, has been the subject of dispute throughout the centuries, ecstatic/erotic trance dance has experienced acute marginalisation (Ehrenreich 2006; Jackson 2004). In spite of this, in recent decades ecstatic dance cultures have flourished as clubbing, raving, trance, hip hop, etc, have proliferated around the world. Despite the slow and lukewarm reaction 
of various academic disciplines, especially cultural studies (see St John 2006), to the presence and significance of EDMC, over the last decade there have been considerable research developments across a range of disciplines. Amid insights revealed, for example, about ritual (Sylvan 2002: 136-48), festal transgression and the sacred (Gauthier 2004; Gerard 2004) millenarianism and revitalisation (Olaveson 2004; St John 2004b), the turn to "spiritualities of life" (Lynch and Badger 2006), and New Age and alternative spirituality (Beck and Lynch 2009; D’Andrea 2006; Partridge 2006; St John 2004c; Taylor 2001), research consistently identifies contemporary dance cultures as contexts enabling an immediate and sensational sociality approximating a religious or spiritual experience for its participants.

\section{Vibe Tribes}

A common lens within EDMC studies is provided by the anthropologist of comparative ritual and symbolism Victor Turner. Akin to Ndembu ritual, religious pilgrimage and hippy "happenings", raves and dance parties are thought to facilitate "spontaneous communitas". This is where individuals, often strangers to one another, in contexts that are in-between (or liminal) to their routine daily round, and perhaps also collectively undergoing physical ordeals, may experience a spontaneous "flash of mutual understanding on the existential level, and a 'gut' understanding of synchronicity" (Turner 1982: 48). Several commentators have argued that communitas assists explanation for the optimum social dance music experience regarded by participants as the vibe (see Gerard 2004: 178-79; Olaveson 2004: 90; Rill 2006; Siokou 2002; Sommer 2001/02: 73; St John 2008, 2009, 2010a forthcoming; Takahashi and Olaveson 2003: 81; Taylor 2001). In its capacity to "synchronize" music as sound with dancing as movement, Kai Fikentscher maintains that "rhythm" constitutes a critical characteristic of that "energy" underground clubbers regard as "the vibe" (2000: 80), and which is shaped by variables like location, fellow patrons, lighting, décor, costumes and time of night or day, alongside the style of music, volume and tempo. 9 This sensation of "nowness" is repeatedly recognised and interpreted by commentators using a variety of conceptual tools, and thus variously identified as: the "communion" of "trance dance" (Ott and Herman 2003), the "playful vitality" of clubbing (Malbon 1999), the sacrificial consumption of Bataille's "general economy" (Gauthier 2004), the "unity in difference" among German "Technoids" (Hitzler and Pfadenhauer 2002), the "psychedelic communitas" of Australian "doofs" (Tramacchi 2000), the Deleuzian "smooth space” of rave's "becoming” (Jordan 1995), its "connectedness" (Olaveson 2004), or indeed its "vibrancy" (Schütze 2001).

While the vibe might approximate a religious experience for participants, it is of the kind one seeks to reproduce without necessarily being "religious" in the way this is commonly understood (i.e. as institutionalised). The experience is perhaps more precisely spiritual in the sense of the "spiritualities of life" which Paul Heelas (see Heelas and Seel 2003) observes downstream from the turn to subjective or "expressive life" of the 1960s associated with what Thomas Luckmann identified as "secondary institutions" (see Lynch and Badger 2006), and away from the "dictated life" of primary institutions. But while Heelas is preoccupied with a spirituality in which the Self has assumed divine authority, what is curious about the spirituality of the vibe is that it is inter-subjective/inter-corporeal. Revealingly, within EDMCs (especially psytrance) this spiritual experience is commonly translated by participants as "tribal", which appears to signify a desire for a sacred sociality, a social warmth howsoever temporary, 
perceived to have been lost or forgotten in the contemporary world of separation, privatisation and isolation. Not the lonely, cold and calculating "crowds" methodically articulated by Elias Canetti (1962), many of the above approaches offer variant updates on the sacred collective effervescence circumscribed by Emile Durkheim. While the romanticisation of particular indigenous tribal models is indicative to this process (see Newton 1984; Luckman 2003) and while "communitas" may actually be a site for the amplification of divisions based on subculture, class, gender, ethnicity and race see, for instance, Thornton (1995) and Saldhana (2007) - it nevertheless appears to be adopted as a generic signifier, as indicated by manifold examples within EDMC such as Spiral Tribe, Moksha Tribe, Moontribe, and Tribal Records.

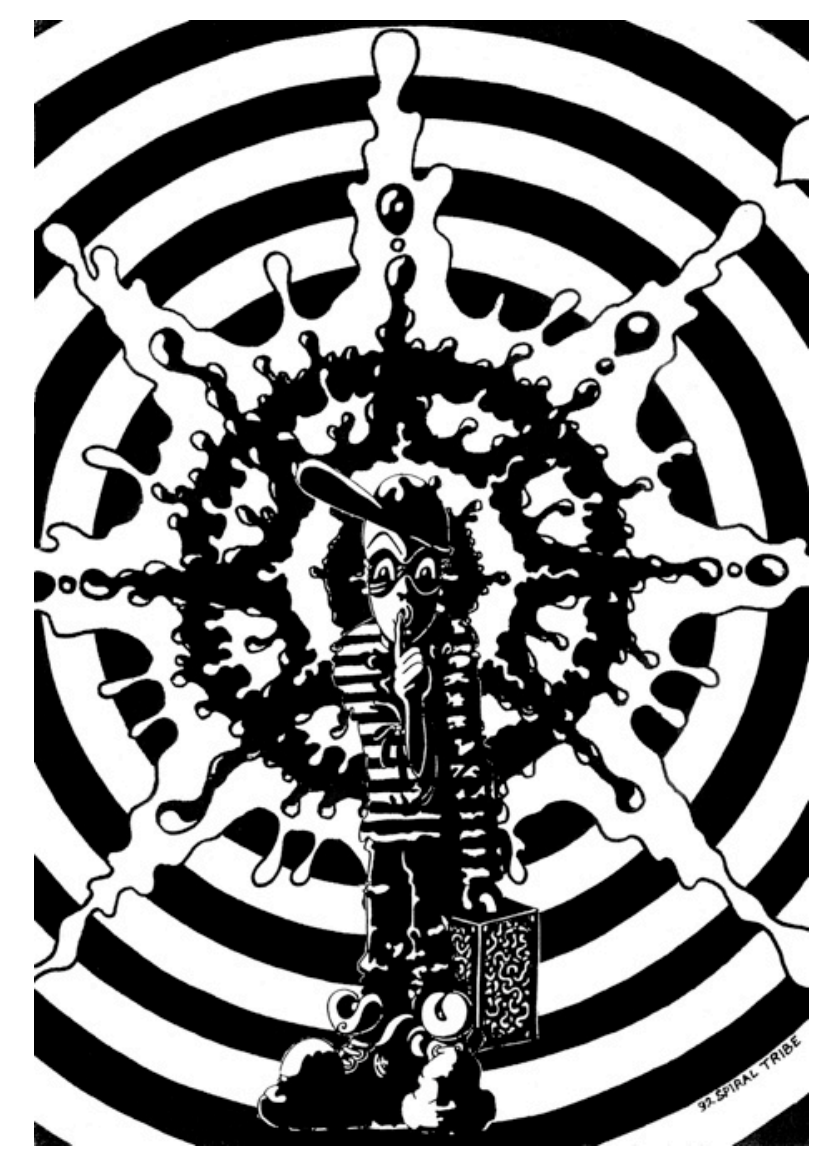

Figure 3: The Shushman / Ninja DJ. Designed by Spiral Mark.

Whatever the precise character of the "vibe", it appears to have become a subject of popular desire, located at the heart of a flourishing social dance movement apparent across multiple genres, and an experience which micro-communities commit to re/ producing globally. Of relevance here is Michel Maffesoli's (1996) theory of "deindividualisation", a model of contemporary social life which attempts to explain the Dionysian commitment among Europeans for assembling and reassembling in passionate "neo-tribes" complementary to, or in place of, crumbling traditional institutions (e.g. Church, nuclear-family, clan, etc). The production and reproduction of 
moments of being together is considered to be a primary commitment of neo-tribes. According to this view, individuals groove between ephemeral sites of empathetic and amplified sociality, with multiple sites existing like portals in a shimmering galaxy. It is little wonder that dance researchers (e.g. Bennett 1999; Gaillot 1999; Gore 1997: 567; Malbon 1998; St John 2009) have found value in this interpretative lens, since, as a contemporary site of belonging and identification, the dance club, party or festival is legion.

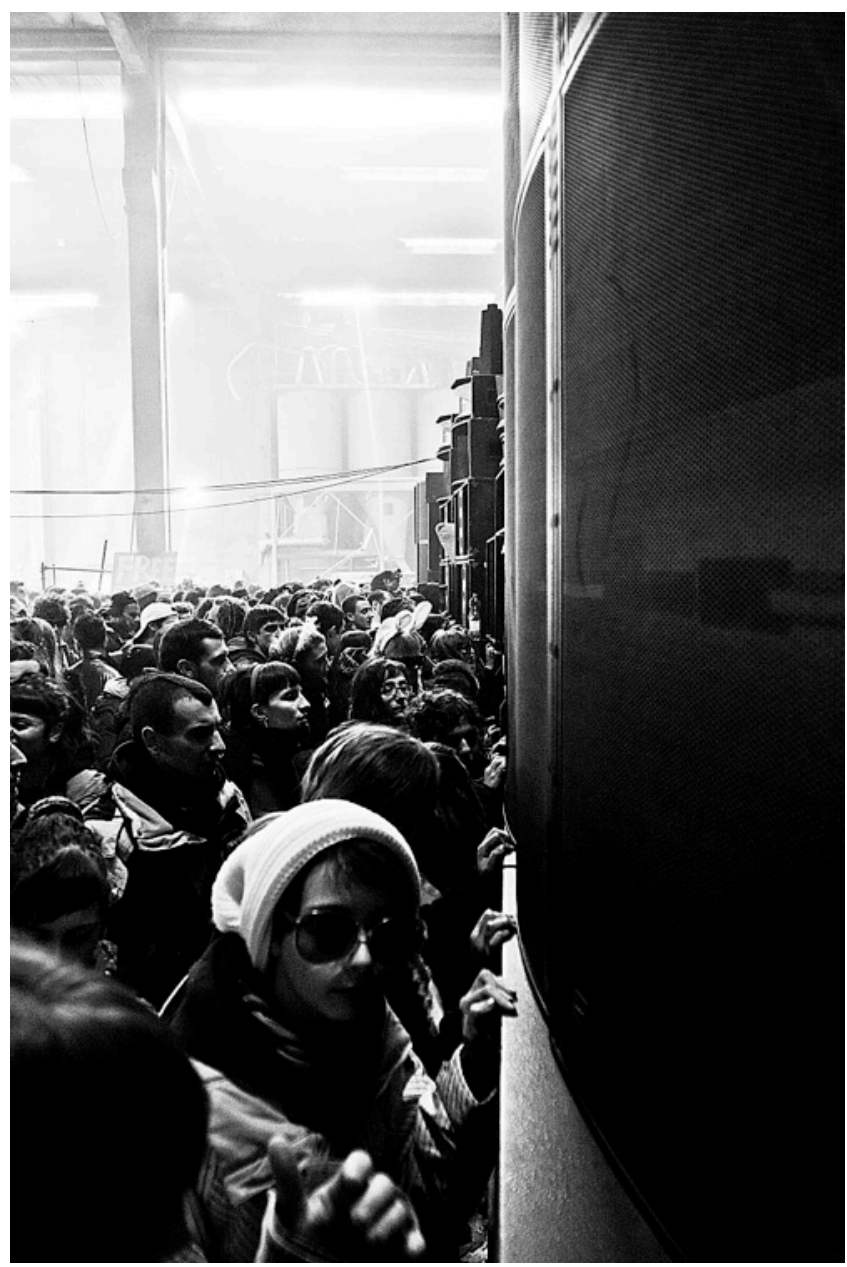

Figure 4: Karnival 2009. Photo by Alex Canezei www.alexcanazei.com

Within pervasive techno-tribes the being together endogenous to the dance vibe is associated with a desire to be united, a coming together of variant and disparate tribes. Bubbling up out of cosmopolitan centres, dance gatherings are convergences of diverse sonic and stylistic universes, sound alliances, fusions of dance tribes and their variant vibes. From the gay African American, Latino disco and house scenes in New York and Chicago, to the ecstatic communions of acid house in London and Manchester, and from the raving diaspora which in North America developed the mythos of peace, 
love, unity and respect (PLUR), to a litany of post-rave genre shards, the tolerance for difference (or at least its ideal) has evolved in a multitude of dancescapes. While enthusiasts would describe the early 1990s San Francisco rave community as a movement ostensibly founding "a new form of liberation theology" (Hill 1999: 97), it appeared that this "rave new world" was inhabited almost exclusively by young, white, participants. The utopic character of dance parties and clubs would nevertheless gain legendary momentum not least since dance floors were understood to be sites of "spectacular disappearance" (Rietveld 1998: 204) permitting the expression of gender, sexual and racial difference shielded from media misrepresentation, prejudice and oppression. In mid-1990s Sydney Park, for instance, Australian "doofs" were events "in which people of all races, sexualities and cultural backgrounds can come together" (Strong 2001: 74), a circumstance providing the precedent for intercultural reconciliation events such as the Exodus Cyber-Tribal Festival and Earthdream 2000 (see St John 2005). In Vancouver, the early rave milieu was marked by the "coming together" of stylistic and aesthetic scenes: "queers, Goths, electro and new wave freaks, cyberpunks, anarchists, activists, S\&M scenesters, tattoo and body modification lovers and dancers" (van Veen 2003: 92). In other cases, senior rave neophytes like Fritz (1999) have articulated epiphanies of acceptance.

One critical aspect of the "tribalism" of the present is that it is characterised by divergent trajectories: designating both the expression of difference and the obliteration of such distinctions. When participants recognise their experience as "tribal" they appear to be fluctuating between these experiences. Thus within dancescapes "tribal" may refer to a particular aesthetic, technique or language by which an individual or group distinguish themselves from an other, or it may refer to the dissolution of such differences. In the first instance, one claims to be affiliated with this or that scene, sensibility, fashion, drug, language, music, etc, with the association and aesthetic infusing one's identity. In the second, "tribal" signifies a dance orgiasm in which such distinctions are transcended in an apocalypse of subjectivity. More likely and more frequently, it designates some conflation of both tendencies, especially since individuals from different "tribes" will already share some aesthetic discourse and practice in common. Event organisations hosting festal environs in which diverse lifestyle affiliates are accommodated, hold a particular dedication to optimising the conditions for their convergence and exchange. In this sense, within the context of the EDM event, "tribal" designates a mode of being together which both accentuates and liquidates difference, albeit temporarily.

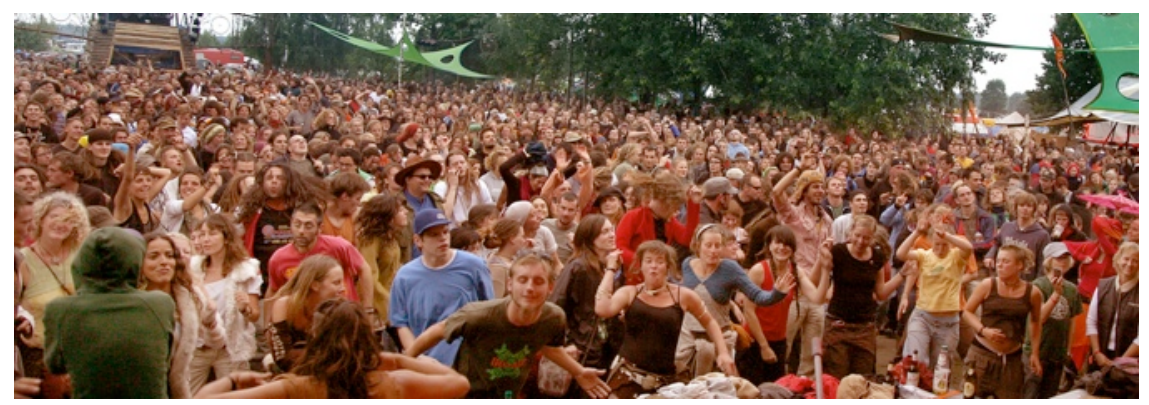

Figure 5: Fusion Festival 2007. Photo by Sam Rowelsky 


\section{Psytrance: Spiritual Techno}

Psytrance is characterised by specific techno-tribal associations committed to (re)producing a distinct vibe. The genre is unique in that its public events are likely the most culturally/nationally diverse dance music events worldwide. It is also of interest here since elements within this movement hold conscious religio-spiritual pretentions. While there is a paucity of published ethnographies configuring the religious and spiritual characteristics of this global movement, Anthony D'Andrea's study (2007) of "global nomads" who are mobile in a freak-diaspora characterised as a digital New Age began to correct this. ${ }^{10}$ Psytrance evolved from Goa trance, which had emerged as a reproducible and sought-after style of electronic dance music by the mid-1990s. With roots in the psychedelic counterculture and EDM developments of the 1980s and 1990 s, psytrance is characterised by a diversity of subgenres, scenes, and concomitant aesthetics. With post-Goa scenes evolving across Europe, Israel, North America, Australia, Japan, South Africa, Brazil, and elsewhere, public events range from smallscale parties to large international festivals, the latter typically accommodating a diversity of sub-scenes and styles. Lasting over-night or perhaps during week-long campouts, events are favourably held in open-air locations where dance floors may be positioned in bushland, forest, beach or deserts, where participants will often celebrate celestial events (e.g. the full moon or a total solar eclipse) or hold parties to mark seasonal transitions.

Psytrance is replete with the characteristics of an alternative spirituality, which has flourished since the 1960s. According to Linda Woodhead, advocates of the "new spirituality" would express commitment to: a spiritual relativism which sees a profusion of religions and symbol systems adopted in the belief that they offer access to similar divine truths; a "new age" of unity, peace and spiritual enlightenment; the understanding that everyday reality manifests "a deep and unifying spirit or life-force" recognisable in the holistic/ecological mantra "All is One"; and an expressive "radical immanence" which sees participants accessing this underlying "life force" or "energy" through direct experience (Woodhead 2001: 81-2). Psytrance carries this cultural continuity of relativism, hope, holism and experience, the latter commitment certainly not the least as detected in the reworking of the Hendrixian question in the title of the debut album of the chief act in the Goa/psytrance movement, Shpongle: Are You Shpongled? (1998). It should also be recognised that psytrance is infused with the reflexive-utilitarian (visionary) and expressive-Dionysian (ecstatic) dimensions of the counterculture that Frank Musgrove had identified as "the dialectics of utopia" (1974: 16). As a vehicle for developments in responsive alternatives to dominant practices and for collective self-abandonment, psytrance constitutes a musical and cultural movement that embraces principal aspects of the 1960s-inspired new spirituality. Festivals like the global Earthdance phenomenon, San Francisco's Synergenesis, or the UK's Turaya Gathering (promoted as a "Holistic World Fusion Arts Gathering"), along with Australia's Rainbow Serpent Festival, or Intention and other events operated by British Columbia's Tribal Harmonix, among other international events and global sites accommodating a host of therapeutic, artistic and ecstatic pursuits, illustrate that the milieu inhabited by psytrance participants is one in which conscious alternatives and transgressive commitments have recombined.

It is more than apparent that psytrance accommodates an eclectic alternative spiritualism featuring occultic characteristics. Christopher Partridge initiated the discussion on psychedelic trance's role in the history of the popular occult or "occulture" 
and, more broadly, the re-enchantment of the West (2004: 166-75; 2006). Drawing on Ernst Troeltsch's and Colin Campbell's understandings of "mystical religion", Partridge holds that an occultism has pervaded contemporary Western culture. This prolific "cultic spirituality" is "self-oriented, eclectic and epistemologically individualistic", while at the same time possessing a tendency to coalesce in networks and organisations which Campbell identified as "the mystic collectivity" (Campbell 1977 in Partridge 2004: 63). Possessing some resemblance to what I have referred to as "tribal", the cultic involves those who, while not forming organised religions (i.e. churches or sects), nevertheless participate in groups and networks forming around shared beliefs. The immediate occultural character of psytrance is illustrated by its proponents' interest in a check-list offered by Partridge (2004: 69): "direct experience of the divine, in secret gnosis, in alchemy, in theurgy, in a philosophia perennis, and in ancient religion and mythical figures, texts and civilizations", along with UFOs, alien abduction and dark Romantic narratives. Enthusiasts adopt a fusion of alternative and popular cultural artifacts and symbolism. Psytrance is thus not only pervaded with Buddhism, Hinduism and other Oriental religious motifs (as a result of an Eastern inflected heritage as seen in tapestry décor, websites and CD covers featuring Lord Shiva, the elephant headed divinity Ganesha or, frequently, the Om symbol) or with indigenous, mystery and esoteric traditions (as inflected in Amerindian prophecy and cosmology), but is suffused with science-futurist and off-planetary narratives. In the "sampladelic" cut-npaste fashion characteristic of the technoccult, the symbolism of traditional tribal groups (Native American, Australian Aboriginal; tepees, didjeridu etc), is mixed with imagined cyborgian mutations, alien encounters and upgrades to galactic citizenship commonly referenced in music samples and fashion. These elements combine to augment personal growth, enlightenment, status, and credibility, complicating the "tribal" identification within the psytrance-imaginary, and rendering rather futile simplified efforts to dismiss formations through critiques of cultural appropriation.

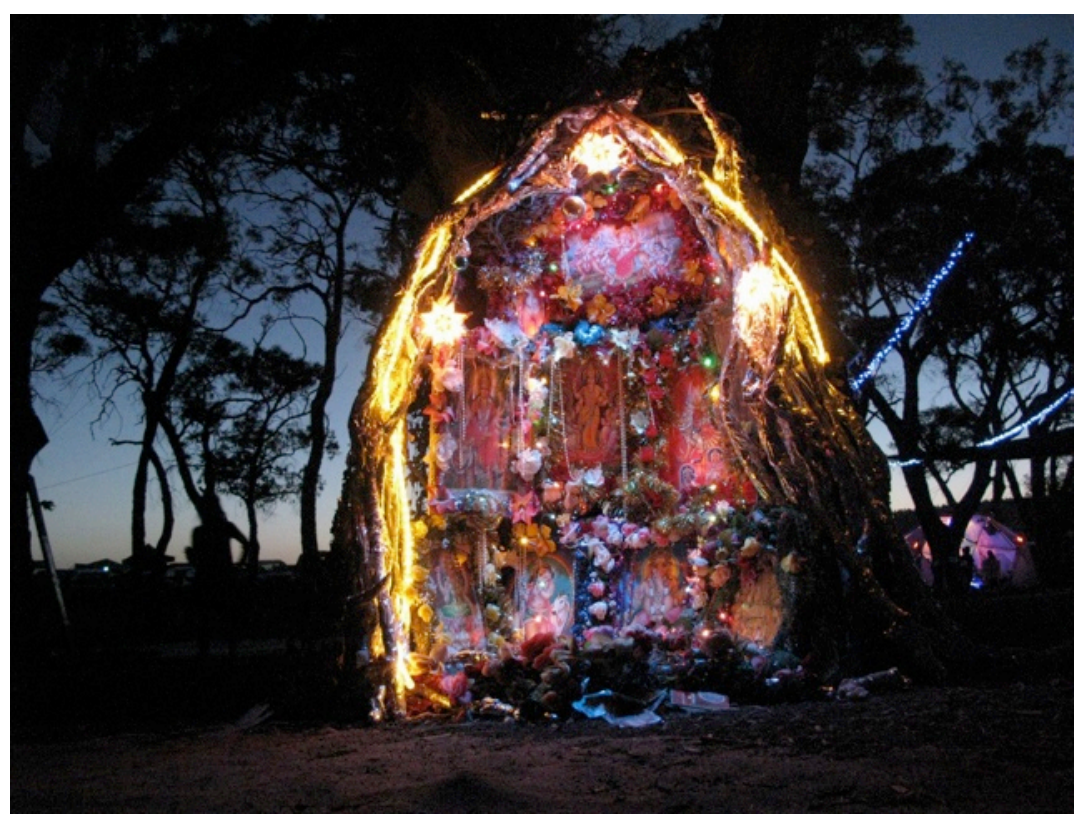

Figure 6: Shrine at Rainbow Serpent Festival, Australia, 2009. Photo by Johanna Hobbs www.flickr.com/photos/johannahobbs 
While the psytrance movement descends from the holistic human potential movement, participants, like their trailblazing countercultural forebears, are "children of technique", heir to many pathways towards the truth, oneness, eternity, belonging. They are what D'Andrea calls "neo-nomads" whose identity is fashioned from a unique dialogue between those clusters of experience and meaning he calls "New Age" and "Techno". That is, identity is formed at the intersecting lines of two different yet complementary "styles of subjectivity formation" under flexible capitalism. Thus, "New Agers cultivate the self as an inner substance to be shaped within holistic ideals, whereas Techno freaks implode the ego during pounding rituals of Gothic digitalism" (D’Andrea 2007: 6, 225). As a decidedly technologically mediated spirituality, psytrance also possesses something of what Erik Davis (1998) calls the "techgnostic" sensibility, where the potential for self-liberation and awakening drives technological development. Davis documents how the techno-liberationist flame, reignited throughout Western history, has conflagrated with the advent of the digital age. The modern millenarian belief that new technologies promise a better future here and now may explain why psytrance, a most technologically sophisticated dance culture evolving in conjunction with advances in audio, cyber and communication technologies throughout the 1990s and into the $21^{\text {st }}$ Century, has become implicated in revitalisation movements and "New Edge" narratives of re-awakening, notably that associated with 2012 and the Mayan Calendar (see St John 2004b). As is common to revitalisation movements, formations and narratives emerge in response to recognised global crises (ie. humanitarian and ecological), with participants defining themselves against dominant modes of thought and practice. Thus psytrance music and culture becomes a repository for experimental knowledge, unorthodox science, heretical religion, and progressive movements.

\section{The Psy-Festival and Neotrance}

Earlier I discussed the vibe, which can be characterised as a context for tribalism, meaning both the expression of difference and its transcendence. As an evolved expression of this dynamic, psytrance festivals enable participants from diverse national, cultural and stylistic backgrounds to give expression to their difference while at the same time potentiating the experience of singularity. In the West, the expression and dissolution of difference is a circumstance traditionally conditioned by the festival of Carnival. It is not my intention here to discuss the complex history of this pre-Lenten Catholic festival, its suspected precursors, nor its Afrodiasporic and Latin and South American developments, but more to draw attention to the "carnivalesque" praxis understood by Mikhail Bakhtin. While Bakhtin observed the carnivalesque condition passing into literature and popular culture, from small free dance parties to larger commercial festivals, the global proliferation of dance cultural events evinces an apparent resurgence of the carnivalesque. As understood in Rabelais and His World, carnival is the people's "second world", an effervescent subterranean enclave including fairs and popular feasts, mummery, dancing, far-out novelties and open-air amusements evident since antiquity. For Bakhtin, "while carnival lasts there is no other life outside it. During carnival time life is subject only to its laws, that is, the laws of its own freedom" (1968: 7). This is a world of spontaneity, laughter and outrageous fun, a licentious landscape of play and immediacy in which habitués become "an indissoluble part of the collectivity", becoming quite literally the body of the people. Amidst the "archaic grotesque" of the dance festival where the body-in-dance outgrows itself, trans- 
gresses its own limits, becomes mutable, "the individual body ceases to a certain extent to be itself ... [as] the people become aware of their sensual, material bodily unity and community" (Bakhtin 1968: 255).

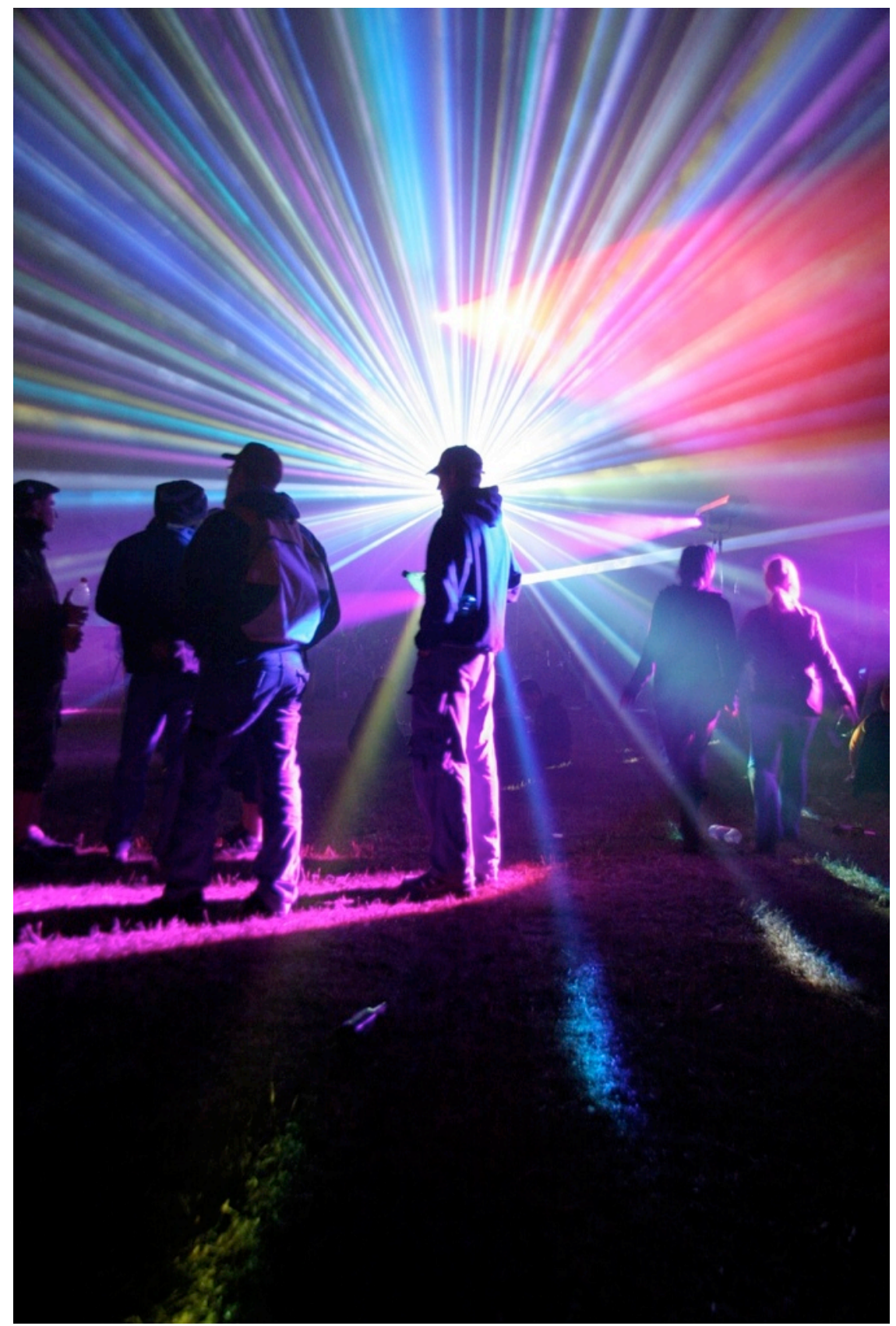

Figure 7: Fusion Festival, Germany 2007. Sam Rowelsky 
It should be recognised, however, that here is a festal culture heavily reliant on the use and repurposing of media technology, audio-visual tools, and remixological practice. In comparing rave with the Bahian Carnival in Brazil, Bernard Schütze (2001: 158) observes that in "carnivalizing the technologies of a command and control society", the rave is positively "technophagic". That is, where the carnival's "anthropophagic principle is based on an incorporation of the other in terms of a cultural cut-n-mix producing hybridity, the technophagic seizes technological means (electronic, pharmaceutical, logistic) and inverts their control and productive function into one of unleashing energies that modulate the vibratory body" (Schütze 2001: 16162). And, like traditional Carnival, the "joyous intermingling, bodily expression, eccentric behaviour and dress" of the techno-rave festival operates an "open transmutation of subjectivities that tears asunder normative modes of subjectivation and permits the experimentation of novel forms of subjectivity". These days, Bahians are not unfamiliar with the beat-matching of carnival with rave. With the advent, for example, of the Universo Parallelo Festival de Arte e Cultura Alternativa near Ituberá, Bahia, a popular international psytrance and "alternative culture" festival in its eighth year over the New Year week 2008-9, the "vibratory body" was heavily modulated by audio, visual, and chemical technologies. In Brazil and worldwide, we might witness, as Hillegonda Rietveld (2004: 53) postulates, a transit to "cyborg-like subjectivity", the product of a postindustrial sacrificial repetitive-beat ritual offering a temporary-yetrelived homeland for the alienated. Invoking Georges Bataille, she writes: " $t \mathrm{t}]$ he peak experience is a trip into the void: time, space and sensory input fragmenting and collapsing, yet held together by the repetitive beat; suspended, the spiritual hedonist is rendered speechless and unable to articulate, being everything and nothing; part of all; complete yet empty."

It is indeed instructive to briefly turn to Bataille's theory of religion, for attention to excess, consumption and the sacred offers insight on the psytrance vibe - and that associated with other EDM cultures - as temporary communities reproduced via personal and collective acts of transgression. That is, as communities reproduced through the routine expenditure of excess energy, and through self-sacrifice in acts of abandonment involving ecstatic dancing often fuelled by chemical cocktails (like LSD and MDMA) and "entheogens"11 (such as charas, fly agaric mushrooms, mescaline, ayahuasca, DMT and salvia divinorum), obtained and prepared for this very purpose. In a Batallian "general economy", the burning up in potlatch-like proportions of that which had been translated as society's "accursed share" constitutes a path towards obtaining a sacred otherness in which formerly separated individuals may share intimately as they "consume profitlessly". "If I thus consume immoderately", states Bataille in The Accursed Share (1988), "I reveal to my fellow beings that which I am intimately: Consumption is the way in which separate beings communicate. Everything shows through, everything is open and infinite between those who consume intensely" (in Gauthier 2004: 76). A dance festival is an exemplary site for this form of communication - especially as dance floor occupants exchange drinks, pass chillum and are subject to sustained bass pressure, a shared chemical and sonorous experience softening the boundaries that may otherwise separate individual participants. With at least 25,000 bodies from over eighty countries connected through persistent rhythms, intense consumption, and self-abandonment on one of the planet's largest EDM dance floors, Boom orchestrates intense moments of communication and a profound sense of belonging to a diverse "psychedelic" community. With the billboarded message "We Are One" backgrounded by lake Idanha-a-Nova, and with participants wearing 
the same message on their wrist-bands (as provided upon entrance), Boom 2006 may be said to have constituted a subterranean body of the people.

That is, at least, the mythology. For while this is indeed the view of organisers and great many event participants, the presence of Anti-Boom, a "teknival" (a freefestival featuring techno sound systems with a distinctive hardcore - and thus not psytrance - aesthetic) operating simultaneously across the lake from Boom, challenges this universalism. Additionally, a considerable number who were refused entry (due to the event reaching capacity) or who complained about entrance fees or deficiencies in services and sanitation in 2008 might very well question this narrative. This contrast is important since, without a gate charge, Anti-Boom might more readily claim the status of a "Temporary Autonomous Zone" (Bey 1991), even though Boom actively promote and support the idea of a "TAZ". To be fair, there is no question that Good Mood/Boom have desired to remain an ethical commercial festival, given, for example, their long standing commitment to remain free of corporate sponsorship, as clearly expressed in the Boom Book (Good Mood 2007).

While the psy-festival is a context for self-immolation in the furnace of dance, it is, at the same time, a context for the performance of the self, the presentation or staging of a persona, which, exceeding that of the routine self, quite literally becomes an other self: indeed, the freaky self. In countercultural history, the freak is never straight, stationary or complete, always somewhere in-between and entirely ambiguous with regard to moral rules, dress codes, gender regulations, disciplined embodiment and legal mind states. Transgressing categories, trespassing psychic limits, seeking forbidden knowledge and drifting between marginal sites, as ontological and territorial nomads, freaks are characterised by movement and uncertainty. Accommodating the creative recombination of aesthetics, undisciplined embodiment and psycho-somatic states, Boom is a freak theatre, a staging-ground for what Turner had called the "subjunctive mood" (Turner 1984: 21), an experimental state or atmosphere where occupants - wearing outfits with theriomorphic (animal-like), anime, superhero, mythical and extraterrestrial themes, adopting stylised (e.g. fractalised and UV reactive) glyphs printed on clothing, badges, and personalised patches, and through innovative dance moves - indulge in alternate personas. The queering of gender, is also not uncommon, with females perfecting androgynous appearances and males adopting effeminate styles. On the dance floor and around the festival site, illuminated under UV lights, caught in lasers, distorted by hypnagogic projections and other advanced lighting techniques, in dreadlocked and shaven hair aesthetics, dermal anchors, tattoos and other body modifications, amid the acrobatics of fire staff and glow poi twirling, club and globe ball juggling, and in spectacularly-altered states of consciousness, participants become freaks on display. While public nudity does not typically extend beyond the clothing-optional lake and its foreshore areas, for an unknown but small percentage of the population, with daily temperatures soaring, dance floor habitués are notably under-dressed, accentuating lithe and queer bodies striking lascivious poses especially down at the Groovy Beach stage. 


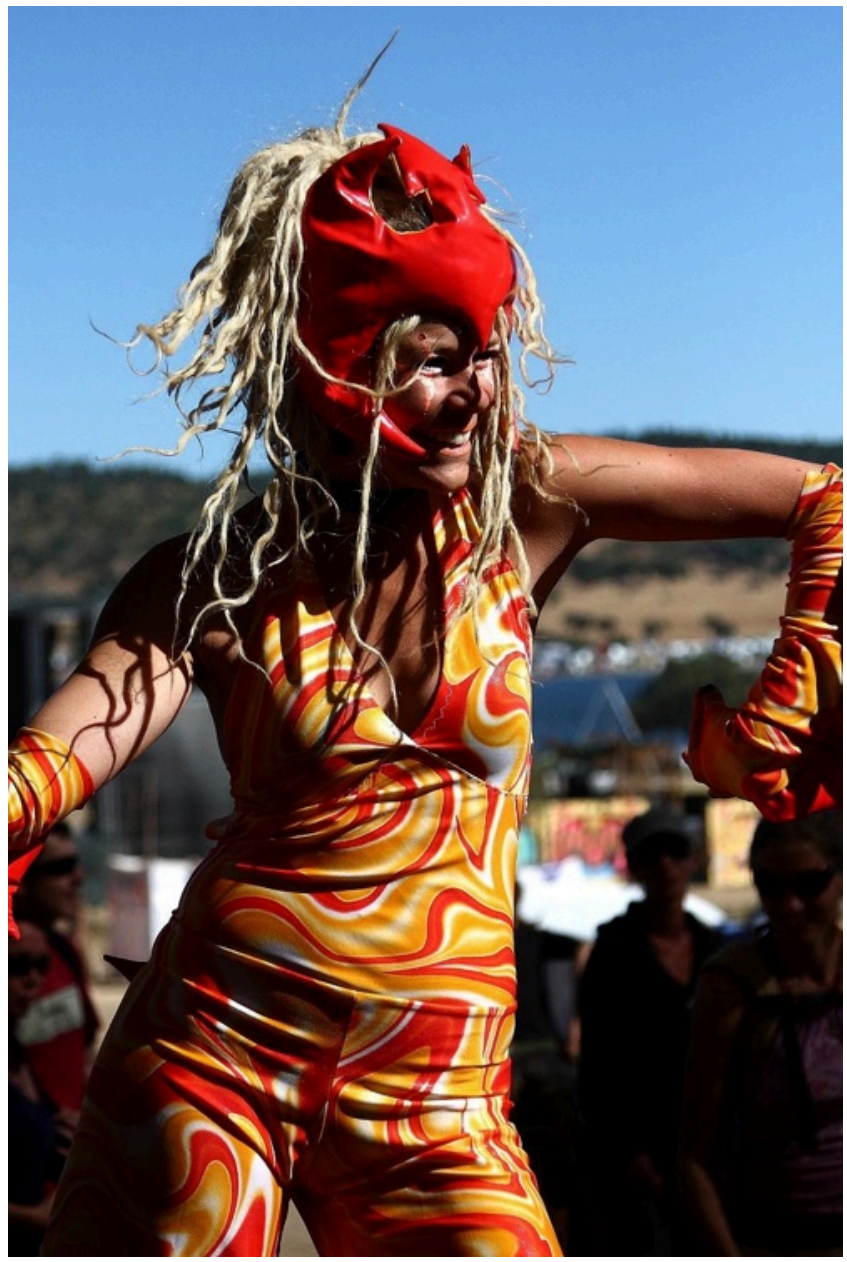

Figure 8: Boom 2008. Photo by Alex Canezei. http://www.alexcanazei.com

The psy-festival, therefore, allows its inhabitants multiple freedoms, including the freedom to join one's flame to the conflagration, and to hold self-promotions on and off the dance floor. Exemplifying the festal-life returning in the contemporary, Boom affords this commotion of singularity and freakiness, the dissolution and presentation of self-hood. Energised in rare fashion, across this spectrum one shifts between spectacular states of self(less)ness. Evincing the complex character of the "tribal" within this movement, participants may experience fusion with, or autonomy from, others in extraordinary states of altered consciousness. ${ }^{12}$ Organisers of Boom, in collaboration with DJs, producers, sound engineers, visual and décor artists, optimise space, time, art and other resources to realise the dynamic I have dubbed neotrance. This concept derives from the suspicion that traditional conceptions of "trance", particularly "possession trance", and especially the analogy with what Emma Cohen (2008) calls "executive possession", are ill-suited to recognise the experiential complexity of dance festal behaviour, and in particular the experience of "trance" endemic to the psychedelic festival, its music, and its dance. In various cultural contexts deriving from West African traditions in particular, patterns of animation identified as "possession" (by Gods and spirits), such as those agents associated with vodu and orisha possession complexes, 
typically serve therapeutic and divinatory purposes in communities where religious specialists, cults and shrines are devotional vehicles for deities and spirits, where altered states are interpreted via inherited religious frameworks, and are integral to the life of communities where human and spirit worlds are intricately interwoven (see Friedson 2005; Keller 2001; Lewis 1971). While the psycho-physiological impact of percussive and rhythmic music (Rouget 1985) may hold across traditional and contemporary trance performance (see Sylvan 2002; Takahashi 2005; Till 2009), and while DJs (and scholars) invoke loose folk-theories of divine guidance, conventional understandings of "spirit possession" tend to offer overstated, unfair and misleading frameworks for understanding "trance" dance cultures associated with contemporary popular music.

Loose contrasts make for an easy dismissal of EDM cultures as comparatively meaningless. Commenting on raves, Goergina Gore (1995: 137-38) claims that, compared with possession trance within cults of the Southern Nigerian Bini, rave is "a rite of passage leading nowhere.... It is a ritual without content, ecstatic, solitary and narcissistic. It is a game of chance; its trance is aleatory and dizzying”. Rave might apparently exemplify the zombification of modern life, a disappearance from meaning, the "zone" entered by ravers perhaps as pathological as that ascribed to the world of gamblers and casinos, an observation which partly explains the poaching from Baudrillard in early rave studies. Illustrating the results of an ethnographic approach to raves which would deliver us closer to the "trance" in question, Melanie Takahashi (2005) seeks to understand the alternative states of consciousness endogenous to these events. She argues that through DJ techniques, optimised audio-visual production and performance, and participant expectations at raves, "technological advancements may compensate for the lack of coherent cultural signifiers" vis-à-vis "the sophisticated scripted process of initiation observed in ceremonial possession" (Takahashi 2005: 253). Ravers remain "horses", only now they are ridden by the spirit of the optimised audio-visual assemblage channelled by the "shaman" DJ. Through these techniques and sound-art strategies, which Morgan Gerard (2004) calls "liminal techniques", by comparison to other popular music forms/techniques, DJs are arguably better able to "control the means of perception" (Takahashi 2005: 254). But while it makes sense to hold inquiry about the capabilities of newer and adapted technologies and chemicals to animate and energise participants, and indeed communities of sound in raves and other EDMC events, persistent analogical modelling with spirit possession becomes somewhat burdensome in itself.

With the objective of revealing the sacred terrain of raving, Gauthier harbours no such intellectual burden. He argues that rave "is not a possession trance, unless perhaps possession by 'nothing'”. Ravers "do not feel 'something' (or indeed 'nothing') is overcoming them. On the contrary, it seems this overwhelming feeling originates from within, only they cannot say how or where" (Gauthier 2004: 78). Further, the experience is "unhinged from a defined and institutionalised - and therefore - explicit religious system that could explicate its meaning. By contrast to a mystical experience, the techno trance is sought in itself and for itself, detached from any defined meaning, aim or purpose". "This trance", Gauthier continues (2004: 79), "is the desire for pure instituancy, pure experimentation with an otherness that remains confused and diffuse - a pure gratuitous act, or a simple gesture of revolt". This argument, I suggest, may be more accurate for "rave" as opposed to psytrance, since the latter is more typically a repository for those practising and experimenting with alternative spiritual dispositions who are open to traverse human/spirit world boundaries outside mainstream 
religious practice and faith (principally that associated with Christianity). This is why organisers, such as those who orchestrated Morocco's Rhythms of Peace psytrance festival, sought to associate their events, in that instance, with master practitioners of Moroccan Gnawa, or why Sufi dancers were billed for the opening ceremony at Soulclipse total solar eclipse festival in Turkey in March 2006, or why ceremonial dance is performed to didjeridu performed by Aboriginal custodians in the opening ceremony at Australia's annual Rainbow Serpent Festival. In these and other more exemplary cases whereby the EDM assemblage is configured as a rite of passage (see McAteer on Goa Gil 2002; the work of DJ Krusty [2008], or the more intentional "tribes" like The Oracle in Seattle and California's Moontribe), the "trance" experience may be said to hold a function. But while there is a strong will to claim connections with traditional cultures and continuity with (imagined or real) forebears, and while movement insiders readily adopt anthropological concepts, such as those associated with "trance", to make sense of their own activities, such appropriations are not unproblematic. Here I simply want to reiterate the view that in "psytrance" dance floor participants oscillate between the performative edge, where participants enact fantastic and erotic personas often drawn from composite influences, and an experience approximate to dispossession, where trancers find release from a troubled and dispiriting lifeworld. The development of intentional replicated trance ritual techniques with clear cathartic objectives is uncommon. But while there are no master healers, as in Moroccan Gnawa, nor consensual frameworks through which states of animation are interpreted and performed within psychedelic culture (Davis 2001), performative devices do circulate. As I discuss elsewhere (St John 2010a forthcoming, 2010c forthcoming), as carnivalesque figures amounting to folk-tropes, the figures of the alien and the "living dead" zombie allegorise and indeed burlesque the unpredictably transcendent condition of the trance dance floor.

Thus, while the neotrance dynamic seems to possess as many and varying manifestations as there are events, trends, narratives and tropes are apparent. Arun Saldanha (2007) weighs in here arguing that the elimination of difference, or more to the point, racially different differences, at parties evolving (or perhaps more accurately, devolving) in the originary site of psytrance (Goa, India) leads to a "viscosity" of white bodies on the dance floor during the morning session in a Third World contact zone. Here, the desirable state of dispossession is possible only when elements preventing the attainment of this condition are absent, or eliminated. In this case, in his analysis, brown skinned domestic tourists. Here is a viscous white tribalism, perhaps even a freak "crowd crystal" in Canetti's (1962) view, in which the liquidation of difference relies upon its accentuation, where the Maffesolian "being together" is cut with a heavy dose of Deleuzian "striation". It should be recognised, however, that, in evidence across global psytrance events, multiple elements jeopardise the "vibe", where freak concentration is not essentially racial or phenotypical. In a realm of competing expectations, perennial bogeymen (eg. tourists, authorities, "straights") imperil the conditions of self-dissolution, queer performance and "instituant" desire. There are indeed considerable differences in the desires of participants, as has already been stated. Broadly speaking, many who promote an alternative health and ecological lifestyle ethos within the grounds of the larger psytrance event such as Boom rail against excesses associated with dance and drug use, especially the abusive consumption of ketamine and what passes as "ecstasy". There is little space to relate these internal controversies here, but it is important to add that it is the nature of an "alternative cultural heterotopia” (St John 2001) to seek resolution to such contestations through optimi- 
sations over successive events. Given the range of motivations and possible divisions, the goal of inclusivity (of unity in diversity) is a challenging task for Good Mood, with their event effectively brokering the unstable coexistence of the carnivalesque and conscious cause (St John 2010b forthcoming). Nevertheless, the festival is the stage, the laboratory, and the building-site for these optimisations. Unlike the ultimate conservatism of "carnival" praxis in Bakhtin's theory of temporary authorised anarchy (see also Stallybrass and White 1986), the psychedelic festival harnesses a desire to break its own boundaries. As lived utopia, a hedged universe, it holds the potential to exceed its borders, and in certain circumstances is adopted with this purpose in mind. Such might be stated for all festivals, yet the tribal carnival holds a unique intention - as the clearinghouse for a movement which seeks to export its liminality into the everyday. I will now offer explanation for how this came about.

\section{Freak Nation: New Tribal Gatherings}

While psytrance and its culture can be understood by way of the theory of carnival, sacrifice and theatre, the particular characteristics of its festal culture have been shaped within a specific assemblage of technics, orgiastics and revitalising tendencies. That is, it is indebted to the ecstatic/idealistic events of the 1960s, which challenged traditional Judeo-Christian mores, and responded to international humanitarian and ecological crises. Emerging out of the impulse toward cultural transformation building in San Francisco's Haight-Ashbury district in the mid-1960s, a momentous event called the "Gathering of the Tribes for a Human Be-in" was held in Golden Gate Park on 14 January 1967. It was the nadir of the Summer of Love and the event in which over 20,000 people participated had been preceded by New York's USCO technotribal media "happenings" in the early 1960s and their disco Be-Ins of 1966, along with Ken Kesey's and Stuart Brand's Trips Festival and The Love Pageant Rally on October 6, 1966, in the Golden Gate Park panhandle. Editor of the San Francisco Oracle (1966-1968), Allen Cohen, promoted the Gathering of the Tribes as a "meeting-of-the-minds", namely the Berkeley radicals and the Haight-Ashbury hippies (Perry 1984: 122). The watershed event involved, among others, Timothy Leary, Allen Ginsberg, Gary Snyder, Richard (Ram Dass) Alpert, and Jerry Ruben, along with numerous acid rock bands including, of course, The Grateful Dead. Owsley Stanley distributed "White Lightning" LSD, outlawed in California in 1966. It appears that the ecstatic communitas in which thousands participated overflowed in the Berkeley Barb the next day: "The spiritual revolution will be manifest and proven. In unity we shall shower the country with waves of ecstasy and purification. Fear will be washed away; ignorance will be exposed to sunlight; profits and empire will lie drying on deserted beaches; violence will be submerged and transmuted in rhythm and dance" (Perry 1984: 122).

With the Gathering of the Tribes and later events, the hippie nation desired no borders, and it wanted to change the world. Fuelled by psychedelics, and a compulsion to create an alternative society, the 1960s constituted a cultural revolution in the West generating an unprecedented population of counter-culturalists seeking, as Leary inveighed, to "find the others". Within the US and UK in particular, alternative enclaves sprouted up in which fellow seekers could manifest utopian visions, conduct experiments with the mind, body and spirit, exchange knowledge, trade goods and live alternative lifestyles. A new "nation" was being imagined from Manhattan to HaightAshbury to London where, on April 29 1967, 10,000 trippers experienced the epochal 
"14 Hour Technicolor Dream", an "all night rave" at the UFO club in the cavernous Alexandra Palace featuring 40 bands, poets, artists, dancers and a massive central light gantry (Palacios 2001). There was a soundtrack to this postnational "nation": the psychedelic rock of the Grateful Dead and The Pink Floyd in particular. And a disenchanted middle-class youth population - from the idealistic to the deranged - were making a mass exodus to this ostensible "nation" without borders. In the post-1960s period, participants in the freak-nation were emigrating from metropolitan centres and college campuses, with countercultural brokers and seekers transporting their freak show to rural regions. In the UK, hippies discovered ancient trails and established a Free Festival circuit merging psychedelic folk-rock with medieval faryes and markets. From festival to festival, these travellers of "Albion", craftspeople, musicians, performers, healers, traders, were nomadic communards living on site for at least half the year (McKay 1996). "Freak" became a mobile nation with nodes, temporary and often seasonal, proliferating around the world. The freak nation would establish enduring enclaves (communes, squats and multiple occupancy communities), but its generative fonts were temporary autonomous zones and bohemian enclaves mushrooming the world over. This is the story of the heterotopian Stonehenge Free Festival (Hetherington 2000), as it is of the early Glastonbury Festival (McKay 2000), Australia's ConFest (St John 2001), and the seasonal Rainbow Gatherings (Niman 1997) which would become a global phenomenon from the early 1980s, with an event transpiring somewhere on the planet at any given time. It is also the story of Burning Man, the annual freak epicentre in Nevada's Black Rock Desert (see Gilmore and Van Proyen 2005). But during the same period, as a no boundaries philosophy was pursued (see Buenfil 1991; Dearling 1998) and national borders trespassed - with national identities even discarded - freak travellers had been transporting their "state of mind" (Elliott 2010 forthcoming) abroad.

The former Portuguese colony of Goa was a significant enclave in the global circuit, particularly important given its location on the coast of India, long imagined in the West as a source of spiritual growth and enlightenment bequeathing that which became Goa trance and subsequent developments with what Partridge calls "suboccultural capital” (2004: 132). Free-form psychedelic Full Moon parties were thrown on the beaches of Anjuna and Vagator villages in Goa populated by self-exiled travelers, and spearheaded by Goa Gil. From California's Marin County where he was involved with Chet Helm's Family Dog productions, Gil arrived in Goa in 1970 and would later become a sadhu "re-defining", as he has it, "ancient tribal ritual for the $21^{\text {st }}$ century". ${ }^{3}$ These parties would flourish on an international circuit growing increasingly popular as the cost of travel declined. 


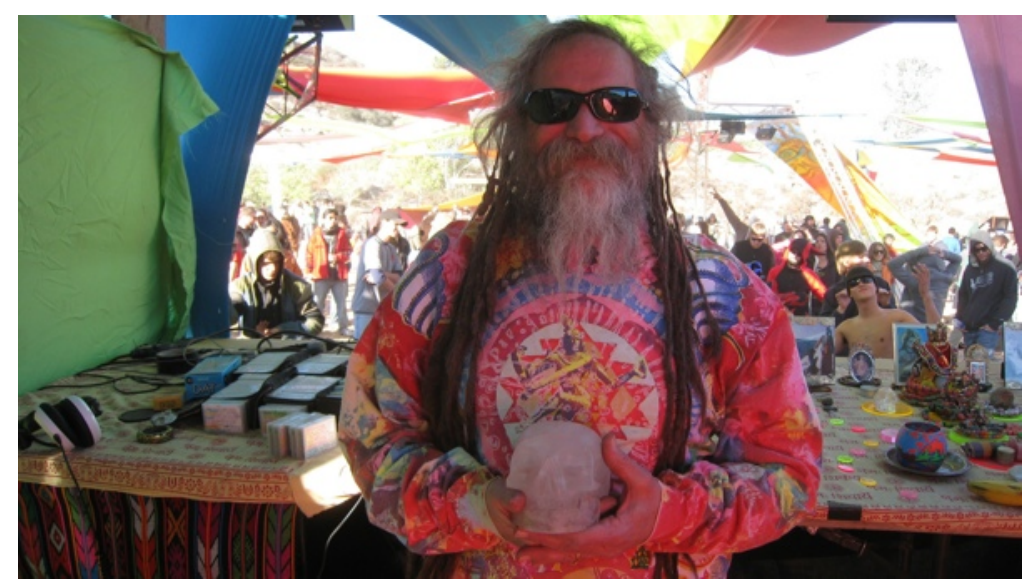

Figure 9: Goa Gil at his 57th Birthday Party, October 2008. Photo by Ariane www.goagil.com

Infused with rapid developments in electronic music production and performance, there developed a network of techno festivals linked in a matrix of alternative sites laid out within and across nations. Goa was thus connected to Ibiza, to the Stonehenge Free, Glastonbury and other festivals of Albion, to San Francisco, Thailand's Koh Phangan, Australia's Byron Bay, Bali, Brazil's Bahia and other emergent countercarnivalesque environs in what Anthony D'Andrea calls a global "freak-ethnoscape" (2004: 240), inclusive of a host of global cosmopoles (De Ledesma 2010 forthcoming; Rietveld 2010 forthcoming). Whether through trade in services (e.g. workshops and therapies) goods (e.g. food, clothing and drugs) or performance (e.g. DJs, VJs sound engineers, décor artists), festivals, clubs and parties within and beyond these zones have become critical hubs for new micro-industries. Becoming sources of income for expatriates and local inhabitants alike, they precipitated tourism and entertainment industries (D'Andrea 2007: 223). Following the success of Goa trance in the mid1990s, the genre exploded into various subgenres and scenes. This international growth was concomitant with the widely proclaimed demise of Goa as a site for authentic experimental trance culture as a result of persistent police, gang and tourist interventions, and media attention (see Saldanha 2007; D'Andrea 2010 forthcoming). By the mid-1990s, the Internet - websites, filesharing platforms, social networking sites, electronic forums etc - would become a critical tool deployed in the service of building labels, operating events and shifting a psytrance sensibility.

By the late 1990s, the psytrance underground was flourishing in global events whose form and commitments owed much to the model provided by the psychedelic Gathering of the Tribes. This is the case with early European festivals like Germany's Voov Experience and with international total solar eclipse festivals, which had emerged in the mid 1990s. But of the regular calendar festivals, Boom is a significant site in the alternative matrix, a periodic zone in the freak nation. Promoted as a weeklong "harmonic convergence of people, energy, information and philosophies from around the planet earth and beyond", Boom features a diverse range of psytrance musics manifesting in dozens of countries. In this inclusive spirit, as Boom's Artur Soares Da Silva indicated to me: "we want to show the full variety, interconnecting different subgenres and to include people from all of the trance countries, so all the countries are represented", a theme which is amplified in the pages of the Boom Book published in 2007 and in a series of DVDs produced on the Boom Festival. ${ }^{14}$ In 2006 and 2008, 
along with the mix of "ambient", "psychedelic progressive", "darkpsy" and "electro" styles introduced earlier, another cross-pollination occurred on an unprecedented scale. With its World Music (or "Sacred Fire") stage accommodating a range of traditional trance acts from Africa, Brazil and Japan, Boom contextualised the convergence of countercultural traditions, from the atavistic to the more techno-oriented. According to co-ordinator of the Sacred Fire, Pedro, Boom 2006 was an ideal location for the Rainbow and trance "tribes", each possessing divergent countercultural trajectories, to converge in a fruitful and creative dialogue. Such is the kind of interfacing facilitated by the gathering that accommodates a cornucopia of difference within its precincts. In this disparate sonicity, different kinds of "noise" accumulate in two diverse arenas, that represent rather polar sites the festival. The Main Stage, which, as I pointed out earlier, must be one of the largest and most sophisticated open-air dance floors planet-wide. This is the principal site for self-performance and dispossession. If the Main Stage is the centre of pleasurable discharge for the week-long event, the fulcrum for symposia concerned with events post-orgy is the Liminal Village, which the final section will now address.

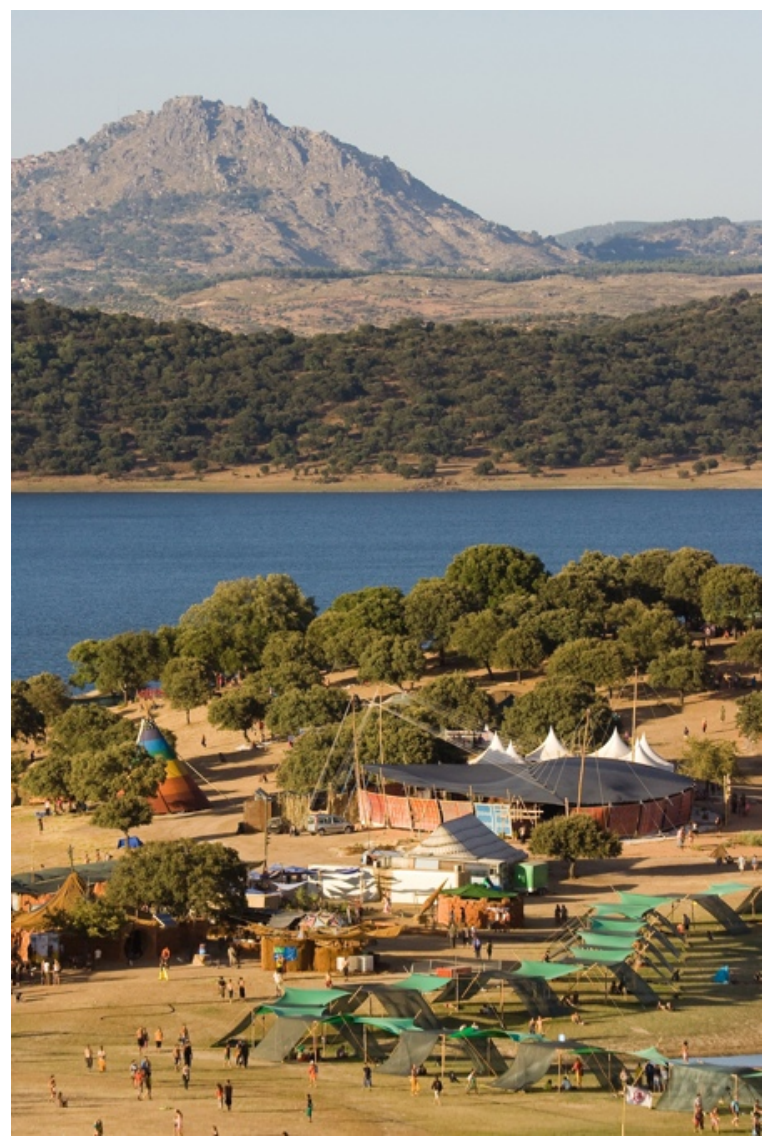

Figure 10: Eco Centre and Liminal Village, Boom Festival 2008, Portugal. Photo by jakob kolar www.jacomedia.net 


\section{The Liminal Village and the Visionary Festival}

Alongside a host of public events studied by cultural anthropologists, and in addition to its ecstatic characteristics, Boom can also recognised as a "cultural drama" (Turner 1982); an event contextualising the transmission of popular cultural values, the amplification of a population's "ultimate concerns"15 surfacing in response to emergent and ongoing crises. As liminal periods of uncertainty, ambiguity and potency, movement events are vehicles for the display, performance and dramatisation of a people's cherished symbols, beliefs and causes upon which various performance genres and media effect inquiry, reflection and possible resolution. In this thinking, an individual's engagement with or contemplation of his or her culture's ultimate concerns, its sacred values and beliefs - its sacra (Turner 1967:102) - is thought to be amplified in such spaces since they are temporarily transported beyond their routines to a space both inbetween and outside day-to-day life. As a "visionary arts" festival responding to crises in the present, Boom offers an intentional rupture of prevailing practice as it transports participants into an alternate space in which divergent pathways are envisioned, explored and lived. By contrast to that which Don Handelman (1990) referred to as "events that model" official sacra, Boom thus attempts to puncture day-to-day life with a reality-field consistent with an alternative future. Offering competing models, alongside other alternative events in various countries, Boom enhances, magnifies or mediates the lifestyles and objectives of its participants, who impregnate the festal interzone with their artistic and political visions, becoming experimental theatres of change, or perhaps in Turner's language, "realms of pure possibility" (Turner 1967: 97).

With an ecological sensibility foremost among its concerns, the Boom Festival should then be understood in the context of commitments (spiritual, political, cultural) arising in response to an ecological crisis, with responses consistent with the broader perception that an ecological consciousness is an ethical responsibility - as found in the objectives of proliferating "sustainability" events such as the UK's Sunrise Celebration and Waveform Festivals and The Symbiosis Festival in California's Sierra Nevada Mountains and Australia’s Maitreya Festival. These, and many other eventorganisations, illustrate that dance practice is integrated with broader movement concerns, an understanding which suggests that the dance "tribe" is rather more proactive than Maffesoli's acquiescent tribalism. Consistent with these events, Boom has become a vehicle for redressive ecological practice. In 2006, Boom featured an EcoVillage with displays and workshops promoting sustainability practices, in addition to experimentation with bio-toilets, showers and site-wide recycling. According to Lucy Legan, co-founder of the Brazilian based Ecocentro IPEC (Instituto de Permacultura e Ecovilas do Cerrado) who was contracted to construct bio-toilets and initiate a reforestation process whereby human feces is transformed into rich soil, these efforts were part of a transit towards an "ecological festival". In 2008, Boom evolved its commitment to provide solutions to the challenges presented by the over consumption of energy, food and water on site, undertaking massive composting, fertilizing, organic waste and water treatment projects, and powering the festival from used vegetable oil, projects for which Boom received a 2008 Greener Festivals award. ${ }^{16}$ 


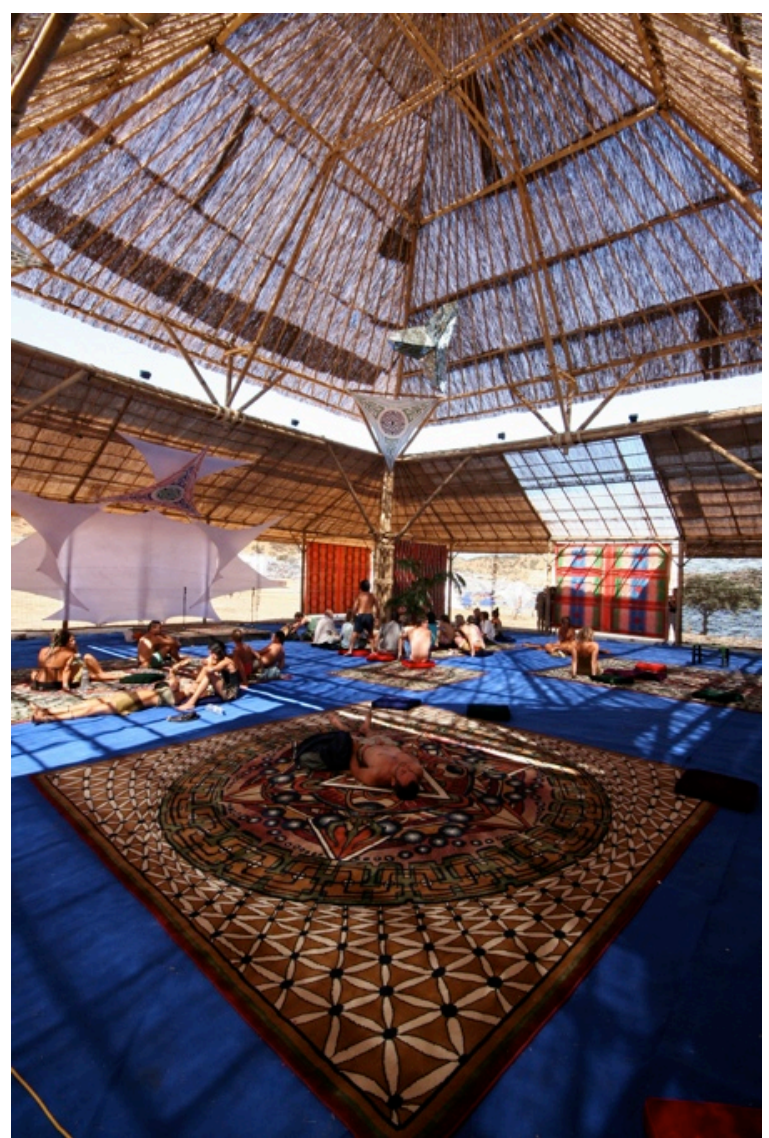

Figure 11: Liminal Village, Boom Festival 2006, Portugal. Photo by jakob kolar www.jacomedia.net

Designed in 2008 using principles adapted from the whole systems approach of permaculture, Boom's Liminal Village is a core site for the articulation of an ecological sensibility. Downstream from earlier models such as London's mid-1990s festi-club Megatripolis, and ultimately San Francisco's Gathering of the Tribes, the Liminal Village has more immediate roots in a Convention area introduced at Boom in 2000. Emerging as the Dynamic Mythologies tent in 2002 the space evolved into its present named "Village" in 2004 when it included the Dynamic Mythologies tent, a Visionary Art Gallery, Healing zone, Dreamspell School and the Multidisciplinary Association for Psychedelic Studies (MAPS) sanctuary. Promoted as a "dynamic confluence of people, traditions, energy and information", taking its place among festivals emerging as "concentrated hubs of exchange and transformation - open systems interzones between the conventional bounds of time and space,",17 the Liminal Village is the culmination of the work of Interchill Records manager, Naasko Wripple, in alliance with a global network of visionary groups. The space is something of "novelty" machine downstream from the interventions of philosopher, ethnobotanist and novelty theorist, Terence McKenna, who was a direct influence on Naasko (as he has been for many others within the psytrance movement). Intentionally harnessing that which organisers understand as the universal experience of ritual liminality - the potent threshold first articulated by Arnold Van Gennep in his study of rites of passage where "liminal" 
comes from "limen", the Latin for "threshold" (1960) - in promoting this space, Boom makes a concerted effort to mobilise liminality and potentiate novelty in the service of a spectrum of causes. Thus, further from Pathways 01 :

In this unique historical moment, liminality holds within it an evolutionary potency.... As we journey together into the liminal, know that this is where art is born. This is where the universal data streams of language, design, spiritual practice and entheogenic experience cross-pollinate and merge into a practical imaginal realm where we can speak, dance, listen and learn. It is here that life becomes a collaborative art project, and life becomes evidence of our evolutionary creativity manifest (Eve the Ladyapples 2006: 5).

Described as a "real-time, open source, visionary experience", and a "global hub of visionary arts and culture", in 2006 the Liminal Village featured several zones including a solar powered bamboo temple, the "Omniplex", the central structure in an alternative educational zone, its "interactive curriculum spotlighting emergent mythologies, integrative philosophies, and techniques for sustainable and holistic living". 18 With workshops, presentations and "metacine" cinema zone, the complex was devoted to the transmission of ecological principles (as demonstrated by permaculture workshops), but a range of other sacra, including: self-healing modalities, psychedelic consciousness, shamanism (including presentations from Graham Hancock and Daniel Pinchbeck, and a "visionary art" gallery called the "Innervisions Gallery"). Organisers desired to transport the temporary citizens of this large bamboo complex to, as promotions had it, "the outer limits of consciousness" recognizing that travelers must depart "the liminal space back into the material, everyday world of our immediate locale", the integration with which is "both a personal and a community function of re-evaluation and re-contextualization". Finally, from "our collective experiences at the edge of everything we can begin to make sense of our unique place in history and to take the important steps towards implementing the evolutionary changes required if humanity and our biosphere are to survive" (Pathways 2006: 9). In 2008, Boom gave considerable attention to figuring technology within its growing ecological agenda. In his observations on the festival, one of that year's Liminal Village speakers, Erik Davis, described the festival as "an incubator of novelty ... A petri dish of possibility where the future forms of community and consciousness are explored". In its efforts to bridge "ritual and party" (Davis 2008: 54), the Boom Festival is identified at the leading edge of conscious festival design, a theme I take up elsewhere in a discussion of the complementarity of ceremonial and carnivalesque behavioural patterns among psytrance enthusiasts (see St John 2010b forthcoming).

Boom's Liminal Village performs like a novelty-machine processing the concerns of populations drawn to psytrance culture; a context within which reflexive practice, ecstatic experience and expressive arts have co-evolved. In its festal architectonics, Good Mood have adopted the power of the "liminal" in their response to the troubled present. In doing so, they ferment ethics, practices and arts sceptical of official narratives and incubate desire echoing the relativist, hopeful, holistic, and experiential characteristics of post-1960s alternative cultural and spiritual movements. The sometimes uncertain partnership comprising the Liminal Village's conscious performances and 
the Dionysian experience on its various dance floors is a festal dynamic traceable to the 1960 s model of the "Gathering". As a "Gathering of the Tribes" some forty years from its precedent, demonstrating inheritance from the tradition of carnival modulated by developments in alternative and electronic dance music culture over several decades, Boom is a psychedelic festival facilitating the simultaneity of fusion and difference I have called neotrance, while at the same time hosting the transgressive/reflexive dynamic implicit to its movement.

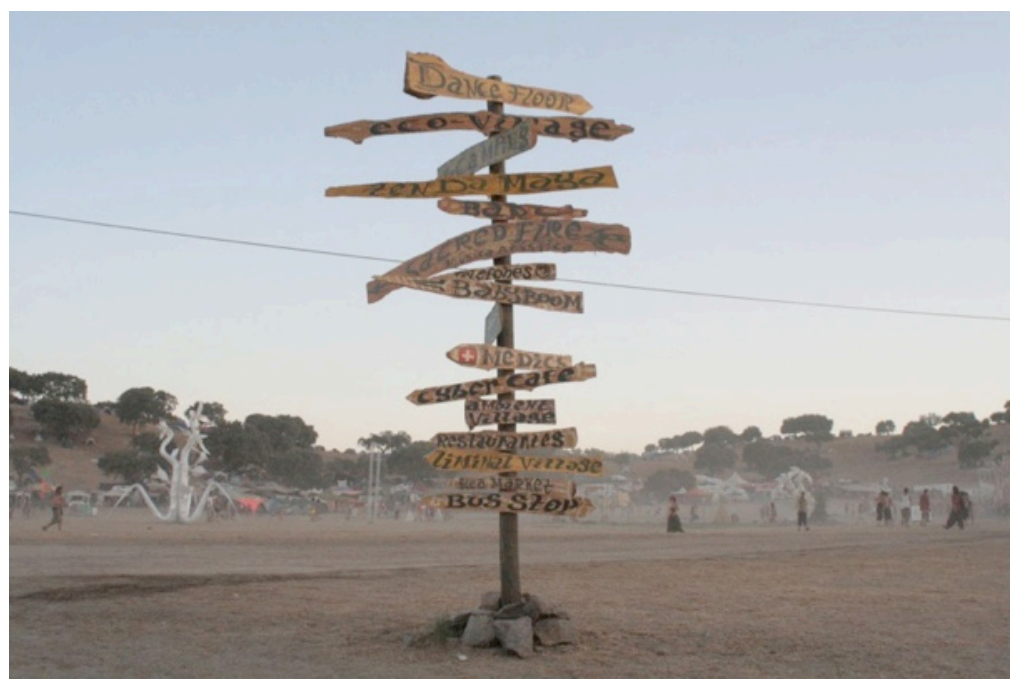

Figure 12: Boom Festival, Portugal, 2006. Photo by Graham St.John

\section{Acknowledgements}

Many thanks to the photographers and designers whose work I have reproduced in this article: Ariane, Alex Canezei, Johanna Hobbs, Jacob Kolar, Spiral Mark and Sam Rowelsky. Thanks also to François Gauthier for reading and commenting on an earlier manuscript.

\section{References}

Bakhtin, Mikhail. 1968 [1944]. Rabelais and His World. MIT Press.

Bataille, Georges. 1988. The Accursed Share: An Essay On General Economy. Vol. 1 Consumption. Trans Robert Hurley. New York: Zone.

Bennett, Andy. 1999. "Subcultures or Neo-Tribes? Rethinking the Relationship Between Youth, Style and Musical Taste". Sociology 33(3): 599-617.

Bey, Hakim. 1991. TAZ: The Temporary Autonomous Zone - Ontological Anarchy and Poetic Terrorism. New York: Autonomedia.

Good Mood Productions. 2007. Boom Book. Portugal. Good Mood Productions.

Buenfil, Alberto, Ruz. 1991. Rainbow Nation Without Borders: Toward an Ecotopian Millennium. Santa Fe: Bear \& Co.

Canetti, Elias. 1962 [1960]. Crowds and Power. New York: The Noonday Press. 
Cohen, Emma. 2008. "What is Spirit Possession? Defining, Comparing, and Explaining Two Possession Forms". Ethnos 73(1): 101-26.

Cole, Fred, and Michael Hannan. 1997. "Goa Trance." Perfect Beat 3(3):1-14.

D’Andrea, Anthony. 2004. "Global Nomads: Techno and New Age as Transnational Countercultures in Ibiza and Goa." In Graham St John (ed.) Rave Culture and Religion, pp. 23655. London: Routledge.

----. 2006. "The Spiritual Economy of Nightclubs and Raves: Osho Sannyasins as Party Promoters in Ibiza and Pune/Goa". Culture and Religion 7(1): 61-75.

----. 2007. Global Nomads: Techno and New Age as Transnational Countercultures. London/ New York: Routledge.

----. 2010 Forthcoming. "The Decline of Electronic Dance Scenes: The Case of Psytrance in Goa". In Graham St John (ed) The Local Scenes and Global Culture of Psytrance. New York: Routledge.

Davis, Erik. 1998. Techgnosis: Myth, Magic and Mysticism in the Age of Information. Harmony Books.

----. 2001. "Psychedelic Culture: One or Many?" TRIP Fall. Available online at: http://www.techgnosis.com/mindstates.html (accessed 20 June 2009).

----. 2004. "Hedonic Tantra: Golden Goa’s Trance Transmission." In Graham St John (ed) Rave Culture and Religion, pp. 256-72. London: Routledge.

----. 2008. “The Festival is a Seed”. Pathways: Liminal Zine 02, pp. 50-4.

Dearling, Alan. (ed) 1998. No Boundaries: New Travellers on the Road (Outside of England). Dorset: Enabler Publications.

De Ledesma, Charles. 2010 Forthcoming. "Psychedelic Trance Music Making in the UK: Rhizomatic Craftsmanship and the Global Market Place". In Graham St John (ed) The Local Scenes and Global Culture of Psytrance. New York: Routledge.

Ehrenreich, Barbara. 2006. Dancing in the Streets: A History of Collective Joy. New York: Metropolitan Books.

Elliott, Luther. 2010 Forthcoming. "Goa is a State of Mind: On the Ephemerality of Psychedelic Social Emplacements." In Graham St John (ed) The Local Scenes and Global Culture of Psytrance. New York: Routledge.

Eve the Ladyapples. 2006. "Between Experience and Imagination: A Liminal Invocation." Pathways: Liminal Zine 01: 5 .

Fikentscher, Kai. 2000. "You Better Work!": Underground Dance Music in New York City. Middletown: Wesleyan University Press.

Fritz, Jimi. 1999. Rave Culture: An Insider's Overview. Canada: Smallfry Press.

Friedson, Steven M. 2005. "Where Divine Horsemen Ride: Trance Dancing in West Africa." In Angela Hobart and Bruce Kapferer (eds) Aesthetics in Performance: Formations of Symbolic Construction and Experience, pp 109-28. New York: Berghahn.

Gaillot, Michel. 1999. Multiple Meaning Techno: An Artistic and Political Laboratory of the Present. Paris: Editions des Voir.

Gauthier, François. 2004. “Rapturous Ruptures: The 'Instituant' Religious Experience of Rave.” In Graham St John (ed.) Rave Culture and Religion, pp. 65-84. London: Routledge.

----. .2005. "Orpheus and the Underground: Raves and Implicit Religion - From Interpretation to Critique." Implicit Religion 8(3): 217-65.

Gerard, Morgan. 2004. "Selecting Ritual: DJs, Dancers and Liminality in Underground Dance Music." In Graham St John (ed) Rave Culture and Religion, pp. 167-84. London: Routledge.

Gilmore, Lee and Mark Van Proyen (eds). 2005. Afterburn: Reflections on Burning Man. Albuquerque: University of New Mexico Press.

Gore, Georgina. 1997. “Trance, Dance and Tribalism in Rave Culture.” In Helen Thomas (ed) Dance in the City, pp. 73-83. London: MacMillan Press.

Handelman, Don. 1990. Models and Mirrors: Towards an Anthropology of Public Events. Cambridge: Cambridge University Press. 
Heelas, Paul. and Benjamin Seel. 2003. “An Ageing New Age?” In Grace Davie, Paul Heelas and Linda Woodhead (eds) Predicting Religion: Christian, Secular and Alternative Futures, pp. 229-47. Aldershot: Ashgate.

Hetherington, Kevin. 2000. New Age Travellers: Vanloads of Uproarious Humanity. London: Cassell.

Hill, Desmond. 1999. "Mobile Anarchy: The House Movement, Shamanism and Community." In Thomas Lyttle (ed.) Psychedelics Reimagined, pp. 95-106. New York: Autonomedia.

Hitzler, Ronald and Michaela Pfadenhauer. 2002. "Existential Strategies: The Making of Community and Politics in the Techno/Rave Scene." In Joseph Kotarba and John Johnson (eds), Postmodern Existential Sociology, pp. 87-101. Walnut Creek: Alta Mira.

Hutson, Scott. 2000. "The Rave: Spiritual Healing in Modern Western Subcultures." Anthropological Quarterly 73(1): 35-49.

Jackson, Phil. 2004. Inside Clubbing: Sensual Experiments in the Art of Being Human. Oxford: Berg.

Jordan, Tim. 1995. "Collective Bodies: Raving and the Politics of Gilles Deleuze and Felix Guattari." Body and Society 1(1): 125-44.

Keller, Mary. 2001. The Hammer and the Flute: Women, Power and Spirit Possession. Johns Hopkins University Press.

Krusty, DJ. 2008. "Trance and Dance: Bush Doofs and the Shamanic Vision”. In Rak Razam and Tim Parish (eds) The Journeybook: Travels on the Frontiers of Consciousness, pp. 15-22. Melbourne: Undergrowth.

Lewis, I. M. 1971. Ecstatic Religion: An Anthropological Study of Spirit Possession and Shamanism. Baltimore: Penguin.

Lewis, J. Lowell. and Paul Dowsey-Magog. 1993. "The Maleny Fire Event: Rehearsals Toward Neo-Liminality." The Australian Journal of Anthropology 4(3): 198-219.

Lindop, Robin. 2010 Forthcoming. "From 'Actual' to 'Meta' Genre: Re-evaluating Musical Genre in UK Psytrance". In Graham St John (ed) The Local Scenes and Global Culture of Psytrance. New York: Routledge.

Luckman, Susan. 2003. "Going Bush and Finding One's 'Tribe': Raving, Escape and the Bush Doof." Continuum: Journal of Media and Cultural Studies, 17(3):315-30.

Lynch, Gordon and Emily Badger. 2006. "The Mainstream Post-Rave Club Scene as a Secondary Institution: A British Perspective." Culture and Religion 7(1): 27-40.

MacAloon, J. J. 1984. "Olympic Games and the Theory of the Spectacle in Modern Societies." In John J. MacAloon (ed.) Rite, Drama, Festival, Spectacle: Rehearsals Toward a Theory of Cultural Performance, pp. 241-80. Philadelphia: Institute for Study of Human Issues.

McAteer, Michael. 2002. "'Redefining the Ancient Tribal Ritual for the 21st Century': Goa Gil and the Trance Dance Experience." Paper for Division of Philosophy, Religion, and Psychology, Reed College. <http://www.goagil.com/thesis.html> (accessed 21 May 2009).

McKay, George. 1996. Senseless Acts of Beauty: Cultures of Resistance Since the Sixties. London: Verso.

----. 2000. Glastonbury: A Very English Fair. London: Victor Gollancz.

Maffesoli, Michel. 1996 [1988]. The Time of the Tribes: The Decline of Individualism in Mass Society. London: Sage.

Malbon, Ben. 1998. "Clubbing: Consumption, Identity and the Spatial Practices of EveryNight Life." In Tracey Skelton and G Valentine (eds) Cool Places: Geographies of Youth Cultures, pp. 266-86. London: Routledge.

----. 1999. Clubbing: Dancing, Ecstasy and Vitality. London: Routledge.

Musgrove, Frank. 1974. Ecstasy and Holiness: Counter Culture and the Open Society. London: Methuen and Co.

Newton, Janice. 1988. "Aborigines, Tribes and the Counterculture." Social Analysis 23: 53-71.

Niman, Michael. 1997. People of the Rainbow: A Nomadic Utopia. Knoxville. The University of Tennessee Press. 
Olaveson, Tim. 2004. "“Connectedness" and the Rave Experience: Rave as New Religious Movement?" In Graham St John (ed.) Rave Culture and Religion, pp. 85-106. London: Routledge.

Ott, Bill and Brian Herman. 2003. "Mixed Messages: Resistance and Reappropriation in Rave Culture." Western Journal of Communication 67(3): 249-70.

Palacios, Julian. 2001. "Syd Barrett: Lost in the Woods." Indica Press. See excerpt at: <http://www.geocities.com/Vienna/Strasse/2724/14hourdream.html> (accessed 11 June 2006).

Partridge, Christopher. 2004. The Re-Enchantment of the West: Alternative Spiritualities, Sacralization and Popular Culture and Occulture (Vol 1). London: T \& T Clark International.

----. 2006. "The Spiritual and the Revolutionary: Alternative Spirituality, British Free Festivals and the Emergence of Rave Culture." Culture and Religion 7(1): 41-60.

Perry, Charles. 1984. The Haight Ashbury: A History. New York: Vintage Books.

Pinn, Anthony B., and Monica R. Miller. (eds) 2009. "Hip Hop and Religion". Special edition of Culture and Religion 10(1).

Reynolds, Simon. 1997. “Rave Culture: Living Dream or Living Death?” In Steve Redhead (ed.) The Clubcultures Reader: Readings in Popular Cultural Studies, pp. 102-111. Oxford: Blackwell.

Rietveld, Hillegonda. 1998. This is Our House: House Music, Cultural Spaces and Technologies. Ashgate.

----. 2004. "Ephemeral Spirit: Sacrificial Cyborg and Communal Soul". In Graham St John (ed.) Rave Culture and Religion, pp. 46-61. London: Routledge.

----. 2010. Forthcoming. "Infinite Noise Spirals: Psytrance as Cosmopolitan Emotion". In Graham St John (ed) The Local Scenes and Global Culture of Psytrance. New York: Routledge.

Rill, Bryan. 2006. "Rave, Communitas, and Embodied Idealism." Music Therapy Today 7(3): 648-61.

Rouget, Gilbert. 1985. Music and Trance: A Theory of the Relations between Music and Possession. Chicago: University of Chicago Press.

Saldanha, Arun. 2007. Psychedelic White: Goa Trance and the Viscosity of Race. University of Minnesota Press.

----. 2010. Forthcoming. "The Ghost of Goa Trance: A Retrospective”. In Graham St John (ed) The Local Scenes and Global Culture of Psytrance. New York: Routledge.

Saunders, Nicholas and Rick Doblin. 1996. Ecstasy: Dance, Trance and Transformation. San Francisco: Quick American Publishing Company.

Saunders, Nick, Anja Saunders, and Michelle Pauli. 2000. In Search of the Ultimate High: Spiritual Experiences Through Psychoactives. London: Rider.

Schmidt, Joshua. 2006. "Fused by Paradox: The Challenge of Being an Israeli Psy-trancer." M.A. Thesis, Ben-Gurion University of the Negev.

Schutze, Bernard. 2001. "Carnivalesque Mutations in the Bahian Carnival and Rave Culture." Religiologiques 24: 155-63.

Siokou, Christine. 2002. "Seeking the Vibe." Youth Studies Australia 21(1), 11-18.

Sommer, Sally. 2001. "C'mon to my House: Underground-House Dancing." Dance Research Journal 33(2), 72-86.

Stallybrass, Peter and Allon White. 1986. The Politics and Poetics of Transgression. London: Methuen.

Stephenson, W. 2003. "Scoring Ecstasy: MDMA, Consumerism and Spirituality in the Early Fiction of Irvine Welsh." Journal for Cultural Research 7(2): 147-63.

St John, Graham. 2001. "Alternative Cultural Heterotopia and the Liminoid Body: Beyond Turner at ConFest." The Australian Journal of Anthropology 12(1): 47-66.

----. (ed). 2004a. Rave Culture and Religion. London: Routledge. 
----. 2004b. "Techno Millennium: Dance, Ecology and Future Primitives." In Graham St John (ed.) Rave Culture and Religion, pp. 213-35. London: Routledge.

----. 2004c. "The Difference Engine: Liberation and the Rave Imaginary." In Graham St John (ed.) Rave Culture and Religion, pp. 19-45. London: Routledge.

----. 2005. "Outback Vibes: Sound Systems on the Road to Legitimacy." Postcolonial Studies: Culture, Politics, Economy 8(3): 321-36.

----. 2006. "Electronic Dance Music Culture and Religion: An Overview." Culture and Religion 7(1): 1-26.

----. 2008. "Trance Tribes and Dance Vibes: Victor Turner and Electronic Dance Music Culture." In Graham St John (ed.) Victor Turner and Contemporary Cultural Performance, pp. 149-73. New York: Berghahn

----. 2009. Technomad: Global Raving Countercultures. London: Equinox.

----. 2010a Forthcoming. "The Vibe of the Exiles: Aliens, Afropsychedelia and Psytrance." In tobias van Veen (ed) Afrofuturism. Wayne State University Press.

----. 2010b Forthcoming. "Liminal Culture and Global Movement: The Transitional World of Psytrance." In Graham St John (ed) The Local Scenes and Global Culture of Psytrance. New York: Routledge.

----. 2010c Forthcoming. "Rave from the Grave: Dark Trance and the Return of the Dead". In Cory James Rushton and Christopher M. Moreman (eds) Interdisciplinary Collection of Essays on the Zombie.

----. Forthcoming. Global Tribe: Religion, Technology and Psytrance. London: Blackwell.

Strong, Peter. 2001. "Doofstory: Sydney Park to the Desert." In Graham St John (ed.) FreeNRG: Notes From the Edge of the Dance Floor, pp. 9-36. Altona: Common Ground. $<$ http://undergrowth.org/freenrg notes from the edge of the dancefloor $>$ (accessed 21 June 2009).

Sylvan, Robin. 2002. Traces of the Spirit: The Religious Dimensions of Popular Music. New York: New York University Press.

----. 2005. Trance Formation: The Spiritual and Religious Dimensions of Global Rave Culture. New York: Routledge.

Takahashi, Melanie. 2005. "Spirituality Through the Science of Sound: The DJ as Technoshaman in Rave Culture". In Michael J. Gilmour (ed) Call Me the Seeker: Listening to Religion in Popular Music, pp. 239-66. Continuum.

Takahashi, Melanie and Tim Olaveson. 2003. "Music, Dance and Raving Bodies: Raving as Spirituality in the Central Canadian Rave Scene." Journal of Ritual Studies 17(2): 72-96.

Taylor, Timothy D. 2001. Strange Sounds: Music, Technology and Culture. New York: Routledge.

Thornton, Sarah. 1995 Club Cultures: Music, Media And Subcultural Capital. Cambridge: Polity Press.

Till, Rupert. 2009. "Possession Trance Ritual in Electronic Dance Music Culture: A Popular Ritual Technology for Reenchantment, Addressing the Crisis of the Homeless Self, and Reinserting the Individual into the Community". In Chris Deacy (ed) Exploring Religion and the Sacred in a Media Age, pp, 169-87. Ashgate.

Tramacchi, Des. 2000. "Field Tripping: Psychedelic Communitas and Ritual in the Australian Bush." Journal of Contemporary Religion 15(2): 201-13.

----. 2004. "Entheogenic Dance Ecstasis: Cross-Cultural Contexts". In Graham St John (ed) Rave Culture and Religion, pp. 85-106. London: Routledge.

----. 2006. "Vapours and Visions: Religious Dimensions of DMT Use." Doctoral Dissertation. Department of Religion. University of Queensland, Brisbane.

Turner, Victor. 1967. "Betwixt and Between: The Liminal Period in Rites de Passage." In Victor Turner, The Forest of Symbols: Aspects of Ndembu Ritual, pp. 93-111. Ithaca: Cornell University Press.

----. 1982. From Ritual to Theatre: The Human Seriousness of Play. New York: PAJP. 
----. 1984. "Liminality and the Performative Genres." In John J. MacAloon (ed.) Rite, Drama, Festival, Spectacle: Rehearsals Towards a Theory of Cultural Performance, pp. 19-41. Philadelphia: Institute for Study of Human Issues.

Van Gennep, Arnold. 1960 [1909]. The Rites of Passage. London: Routledge and Kegan.

Van Veen, Tobias., C. 2003 "It's Not a Rave." Journal for the Arts, Sciences and Technology 1(2): 90-6

Wagner, Ann. 1997. Adversaries of Dance: From Puritans to the Present. Urbana and Chicago: University of Illinois Press.

Woodhead, Linda. 2001. "Liberal Christianity and Alternative Spiritualities: The World's Parliament of Religions and the Rise of Alternative Spirituality". In Linda Woodhead (ed.) Reinventing Christianity: Nineteenth-Century Contexts. Aldershot: Ashgate.

\section{Filmography}

Good Mood Productions, Boom Festival 04: A Timeless Psydocumentary, 2005 [DVD].

----. Boom Festival 06: We Are One, 2006. [DVD].

----. Boom Festival 08: We Are All, 2008. [DVD].

Rood, Billy and Torsten Kilmmer. 2002. Liquid Crystal Vision. US. [DVD]

http://www.imdb.com/title/tt0385839/\#comment

\section{Discography}

Shpongle. 1998. Are You Shpongled? Twisted Records (CD, Album) TWSCD4 UK. http://www.discogs.com/Shpongle-Are-You-Shpongled/release/27195

\section{Author Biography}

Graham St John is a Research Associate at the Centre for Critical and Cultural Studies at the University of Queensland and was recently a Postdoctoral Research Fellow in Interactive Media and Performance at the University of Regina, Saskatchewan. His latest book Technomad: Global Raving Countercultures (Equinox) will be published in September 2009. He is the Executive Editor of Dancecult. See: www.edgecentral.net

\section{Notes}

1 Employing a diverse range of theoretical and methodological approaches. See St John (2004a, 2006 and the other contributions to that special edition of Culture and Religion). For other accounts specifically addressing the religiosity of EDMC, see D'Andrea (2007), Gauthier (2005), Hutson (2000), Sylvan (2002, 2005), Takahashi (2005), Takahashi and Olaveson (2003), and Tramacchi (2000). See also the recent edition of Culture and Religion edited by Pinn and Miller (2009) on hip hop and religion.

2 The official figure on both occasions.

3 <http://www.boomfestival.org> (accessed 9 June 2008).

4 In 2006, most of the main structures, including the sound floors, manifested a Balinese design influence. The Main Floor, for instance, was a tall a bamboo pagoda. 

http://www.welcomehome.org/rainbow/index.html> (accessed 12 June February 2009).

6 All of the styles mentioned are subsumed within what Robin Lindop (2010 forthcoming) indentifies as the psytrance "meta-genre", which is rooted in Goa trance. For a musicological analysis of "Goa trance" see Cole and Hannan (1997), and for a detailed description of psytrance musical structure see the online article by Kenny Easwaran "Psytrance and the Spirituality of Electronics": $<$ http://www.ocf.berkeley.edu/ easwaran/papers/psytrance.html> (accessed 9 February 2009). For example, the fundamentalist Christian website "www.truthaboutrave.com", which was active between 2004-06 when it proclaimed to reveal the awful truth about raving, appeared to resurrect the Puritan tracts of the likes of Increase Mather, for whom the heat of the rave dance floor would undoubtedly have signified one's proximity to the devil. Yet, this was not penned in the $17^{\text {th }}$ Century: "Raves are a means of the devil to solicit worship. The Raver who commits himself to ingest drugs and dance the night away is unsuspectingly presenting his entire body as an instrument to express worship to demons and satan."

See Richard Spurgeon's "Rave - The Awakening": <http://www.rave-theawakening.com> (accessed 13 May 2006).

While Fikentscher's valuable assessment is based on the DJ-dancer interaction, and the role of rhythm as a "synchronizing" force, as I elsewhere demonstrate, motivation and intention modulate the "collective energy" (St John 2009).

For further work specifically addressing the religio-spiritual dimensions of Goa/ psytrance, see McAteer (2002), Davis (2004), D’Andrea (2004, 2006), (St John 2004b, $2010 \mathrm{~b}$ forthcoming) and Beck and Lynch (2009).

11 "Entheogen" refers to psychoactive compounds which ostensibly "evoke the divine within". As Jonathon Ott describes "Entheogen [ic] was proposed as a name for a subclass of psychotropic or psychoactive plants (and, by extension, their active principles and derivatives 'both natural and artificial'), as a broad term to describe the cultural context of use, not specific chemistry or pharmacology; as an efficient substitute for cumbersome terms like shamanic inebriant, visionary drug, plant-sacrament, and plant-teacher" (Ott, 1996: 205 in Tramacchi 2006: 20. Ott's italics).

12 Between these states, and indeed outside the dance floor, yet within the precincts of the trance event, one encounters more ordinary conditions which may involve watching others dancing, conversations between friends (perhaps reviewing past events), or planning and logistics for the near future. That such are also part of the "trance" experience, further complicates this subject. $<$ http://www.goagil.com/> (accessed 22 March 2009).

The DVDs include: Boom Festival 04: A Timeless Psydocumentary, 2005; Boom Festival 06: We Are One, 2006; Boom Festival 08: We Are All, 2008.

A phrase used by Paul Tillich (and cited in MacAloon, 1984: 250-54, and Lewis and Dowsey-Magog 1993).

All projects are documented in short films on the Boom Festival 08: We Are All DVD.
From the first edition of the in-Village publication, the "liminal zine" Pathways.

"Transmissions from the Edge": < http://boomfestival.org/> (accessed 9 February 2008). 